Research article

\title{
Heterogeneity of mammary lesions represent molecular differences
}

\author{
Ruria Namba1, Jeannie E Maglione ${ }^{2}$, Ryan R Davis ${ }^{1}$, Colin A Baron ${ }^{1}$, \\ Stephenie Liu'1, Condie E Carmack ${ }^{3}$, Lawrence JT Young2, \\ Alexander D Borowsky1,2, Robert D Cardiff1,2 and Jeffrey P Gregg*1
}

\begin{abstract}
Address: ${ }^{1}$ Department of Pathology and Laboratory Medicine, School of Medicine, University of California at Davis, Sacramento, CA, 95817, USA, ${ }^{2}$ Center for Comparative Medicine, University of California at Davis, Davis, CA 95616, USA and ${ }^{3}$ Agilent Technologies, Deer Creek Rd, Palo Alto, CA 94304, USA
\end{abstract}

Email: Ruria Namba - rnamba@ucdavis.edu; Jeannie E Maglione - jemaglione@yahoo.com; Ryan R Davis - rrdavis@ucdavis.edu; Colin A Baron - cabaron@ucdavis.edu; Stephenie Liu - sliu@ucdavis.edu; Condie E Carmack - condie_carmack@non.agilent.com; Lawrence JT Young - ljtyoung@ucdavis.edu; Alexander D Borowsky - adborowsky@ucdavis.edu; Robert D Cardiff - rdcardiff@ucdavis.edu; Jeffrey P Gregg* - jpgregg@ucdavis.edu

* Corresponding author

Published: 05 December 2006

BMC Cancer 2006, 6:275 doi:10.1 186/I47|-2407-6-275
Received: 31 July 2006

Accepted: 05 December 2006

This article is available from: http://www.biomedcentral.com/147I-2407/6/275

(c) 2006 Namba et al; licensee BioMed Central Ltd.

This is an Open Access article distributed under the terms of the Creative Commons Attribution License (http://creativecommons.org/licenses/by/2.0), which permits unrestricted use, distribution, and reproduction in any medium, provided the original work is properly cited.

\begin{abstract}
Background: Human breast cancer is a heterogeneous disease, histopathologically, molecularly and phenotypically. The molecular basis of this heterogeneity is not well understood. We have used a mouse model of DCIS that consists of unique lines of mammary intraepithelial neoplasia (MIN) outgrowths, the premalignant lesion in the mouse that progress to invasive carcinoma, to understand the molecular changes that are characteristic to certain phenotypes. Each MIN-O line has distinguishable morphologies, metastatic potentials and estrogen dependencies.
\end{abstract}

Methods: We utilized oligonucleotide expression arrays and high resolution array comparative genomic hybridization $(\mathrm{aCGH})$ to investigate whole genome expression patterns and whole genome aberrations in both the MIN-O and tumor from four different MIN-O lines that each have different phenotypes. From the whole genome analysis at $35 \mathrm{~kb}$ resolution, we found that chromosome I, 2, 10, and II were frequently associated with whole chromosome gains in the MIN-Os. In particular, two MIN$O$ lines had the majority of the chromosome gains. Although we did not find any whole chromosome loss, we identified 3 recurring chromosome losses (2FI-2, 3E4, I7E2) and two chromosome copy number gains on chromosome II. These interstitial deletions and duplications were verified with a custom made array designed to interrogate the specific regions at approximately 550 bp resolution.

Results: We demonstrated that expression and genomic changes are present in the early premalignant lesions and that these molecular profiles can be correlated to phenotype (metastasis and estrogen responsiveness). We also identified expression changes associated with genomic instability. Progression to invasive carcinoma was associated with few additional changes in gene expression and genomic organization. Therefore, in the MIN-O mice, early premalignant lesions have the major molecular and genetic changes required and these changes have important phenotypic significance. In contrast, the changes that occur in the transition to invasive carcinoma are subtle, with few consistent changes and no association with phenotype.

Conclusion: We propose that the early lesions carry the important genetic changes that reflect the major phenotypic information, while additional genetic changes that accumulate in the invasive carcinoma are less associated with the overall phenotype. 


\section{Background}

The paradigm that cancer progression is a multi-step process, associated with multiple molecular changes as it progresses from preneoplasia to invasive carcinoma [1], has been challenged by recent molecular data. Gene expression profiling and comparative genomic hybridization (CGH) studies of breast cancer demonstrate that early stages in the human breast cancer such as ductal carcinoma in situ (DCIS), a precursor lesion for invasive carcinoma, has most, if not all, of the molecular attributes of the corresponding invasive carcinoma despite the distinct pathological characteristics [2-5]. This is contrary to the multi-step paradigm that centers on cumulative molecular aberrations with progression. These data suggest an alternative view that the early lesions are already equipped with the molecular changes responsible for tumorigenesis, despite the disparate histological characteristics between the early lesions and the invasive carcinoma.

Breast cancer can be viewed as a heterogeneous disease histopathologically, as well as molecularly. Molecular profiling studies of breast cancer have shown that tumors can be classified into subtypes based on their expression patterns [6-8]. Pathologically, breast lesions are classified by different categories, such as estrogen receptor (ER) status, Her2 status and the degree of differentiation (tumor grade). Both ER and Her2 status are important prognostic factors and portend how a lesion responds to different therapeutic strategies. Both DCIS and invasive ductal carcinoma (IDC) are categorized into three tumor grades [9]. DCIS lesions are also classified into different subtypes by their histological morphology [10]. It is believed that the different classes of lesions have common characteristics that reflect certain clinical outcomes. Gene expression studies of different pathological stages of breast cancer have shown that different tumor grades are associated with distinct expression signatures, confirming the molecular basis for the differences in pathological classification; the same studies show that the profiles of the different stage lesions also have extensive similarities, suggesting that there may not be as many molecular changes associated with tumor progression as was previously thought [4].

Over the last several years, the MIN-O (mammary intraepithelial neoplasia outgrowth) mouse model has been shown to parallel various aspects of human breast cancer development $[11,12]$. MIN (mammary intraepithelial neoplasia) is an early mammary lesion that satisfies the operational definition of premalignancy [13]. The MIN-O mouse was established by transplanting a MIN lesion from a young polyomavirus middle-T $(P y V m T)$ transgenic female mammary fat pad to a host fat pad [14]. The transplanted MIN lesion will grow from the transplanted location to fill the host fat pad. The growth from the transplanted MIN lesion is called MIN-outgrowth (MIN$\mathrm{O})$. Since the MIN-O mouse eventually develops invasive carcinoma within the MIN-O, tumor in this context refers to invasive carcinoma that emerges within the MIN-O tissue. Different lines of MIN-O mice, which were established by transplanting MIN lesions to separate hosts, have characteristic histopathology, metastatic potential, and tumor latency, suggesting that MIN lesions have different biological outcomes despite the same initiating oncogene (PyVmT) [11]. In addition, in depth gene expression studies in one MIN-O mouse line, demonstrated that the MIN-O and tumor tissues show strikingly similar expression profiles between each early premalignant lesion and its corresponding tumor pair [12]. Thus, this model recapitulates the foundation of human DCIS and the heterogeneous nature of the disease.

In the current study, we assessed the correlation between certain biological outcomes to molecular changes associated with four different lines of MIN-O mice. In addition to the gene expression analysis, we report for the first time the utilization of high resolution array comparative genomic hybridization (aCGH) to investigate whole genome aberrations in both the MIN-O and tumor tissue. In addition to this whole genome analysis (35 kb resolution), interstitial deletions were verified with a custom made array designed to interrogate the specific regions at approximately $550 \mathrm{bp}$ resolution. We demonstrate that expression and genomic changes are present in the early premalignant lesions and that these molecular profiles can be correlated to phenotype (metastasis and estrogen responsiveness). Progression to invasive carcinoma was associated with few additional changes in gene expression and genomic organization. Therefore, in the MIN-O mice, early premalignant lesions have the major molecular and genetic changes required and these changes have important phenotypic significance. In contrast, the changes that occur in the transition to invasive carcinoma are subtle, with few consistent changes and no association with phenotype. Therefore, we propose that the early lesions carry the important genetic changes that reflect the major phenotypic information, while the additional genetic changes accumulated in the invasive carcinoma are less associated with the overall phenotype.

\section{Methods \\ Mice}

Standard techniques for mammary gland clearing and mammary tissue transplantation, and the establishment of the MIN-O lines, have been described previously $[11,12]$. Three-week-old FVB female mice were purchased from Charles River Laboratories (Wilmington, MA). Animals were maintained in a vivarium at the University of California Davis campus under IACUC approved protocols. 


\section{Ovariectomy}

To test MIN-O ovarian hormone sensitivity, a $1 \mathrm{~mm}^{3}$ piece of a MIN-O tissue from each line was transplanted in the gland-cleared \#4 fat pads of 3-week-old virgin FVB female mice. At the time of transplantation, the experimental group (ovx, $\mathrm{n}=8$ ) was ovariectomized, while the control group (intact, $n=4$ ) received mock surgery without ovariectomy. At 5 weeks after transplantation, the MIN-O sizes were measured by visually inspecting the transplantation site under a dissecting microscope. Animals were palpated weekly until a tumor was detected. The experiment was concluded at day 99 post-transplantation. For the tumor ovarian hormone sensitivity experiment, 1 $\mathrm{mm}^{3}$ pieces of tumor tissue that developed from various MIN-O lines were transplanted to intact and ovx hosts (at least 2 animals/4 tumors each for a tumor). Both intact and ovx animals were terminated at the same time and the tumor bearing fat pads were weighed.

Immunohistochemistry of formalin fixed tissues using anti-estrogen receptor was performed as previously described [15]. MIN-O transplanted fat pads from the ovariectomy experiment were used to determine the ER localization in the MIN-Os from the intact and ovariectomized hosts.

\section{Mouse Genome CGH Microarrays}

The Agilent Mouse Whole Genome CGH Microarray Kit 44A (G4414A, Agilent Technologies, Santa Clara, CA) consists of roughly 43,000 60-mer oligonucleotide probes that cover both exonic and intronic sequences. These arrays were used to analyze the MIN-Os and tumors from each line. These high resolution arrays have an average spatial resolution of $35 \mathrm{kB}$, after removal of Repeat Masked (-RM) [16]. Agilent uses SurePrint ${ }^{\circledR}$ technology [17] to print this entire content on a standard $1 " \times 3$ " glass slide.
In order to better define the length and boundaries of interstitial regions that were identified as deleted or amplified with the CGH 44A Microarray, a custom array was generated to specifically interrogate these regions at a higher resolution. Four regions were selected for analysis (see Table 1). Approximately $38 \mathrm{~K}$ probes were used to cover these regions for an average spacing of 547 bp (RM). Chromosomes 7 and 8 did not show any interstitial aberrations or whole chromosome aberrations, so 4990 probes on these two chromosomes were utilized for the normalization. In total, each "zoom-in" array contained 44,000 unique probes.

DNA was extracted from frozen MIN-O/tumor pairs isolated from the same fat pads of MIN-O lines $4 \mathrm{w}-4(\mathrm{n}=5$ pairs), $4 \mathrm{w}-11$ ( $\mathrm{n}=3$ pairs), $8 \mathrm{w}-\mathrm{B}(\mathrm{n}=3$ pairs) and $8 \mathrm{w}-\mathrm{D}$ ( $n=3$ pairs). DNA from FVB/NCrl female livers was used as the reference sample. Samples were prepared using the direct labeling method, according to the Oligonucleotide Array-Based CGH for Genomic DNA Analysis Protocol (Version 2.0, available at [18]), with minor modifications of the protocol. A total of $2 \mathrm{ug}$ of digested purified DNA was labeled, using the BioPrime Array CGH Genomic Labeling kit (Invitrogen, Carlsbad, CA), for both the experimental and reference channel. During the labeling, cyanine 3-dUTP and cyanine 5-dUTP (Perkin Elmer, Wellesley, MA) were incorporated in either the experimental or the reference sample. For each sample, two arrays were utilized in a dye-swap pair format, in which the experimental sample and reference sample are each labeled separately with cyanine 3 and cyanine 5, respectively, and combined for the first array, and then labeled in the reverse and combined for the second array. After labeling, the corresponding experimental and reference samples were combined and unincorporated nucleotides were removed on a Microcon YM-30 apparatus (Millipore, Billerica, MA). The purified sample was then hybridized onto a single CGH array in a solution containing Mouse Cot-1 DNA (Invitrogen, Carlsbad, CA), Agilent

Table I: Regions selected for high resolution custom CGH microarrays

\begin{tabular}{|c|c|c|c|c|c|c|}
\hline Chromosomal Interval & Base Pairs & RM Length & Cytobands & Total Probes & Genes & Probe Density (-RM) \\
\hline Chr2:I30057657-I34054840 & $3,997,184$ & $1,593,942$ & $q F I-q F 2$ & 4,393 & 97 & 547 \\
\hline Chr3:82669962-85356557 & $2,686,596$ & 900,443 & $\mathrm{qE} 3-\mathrm{qFI}$ & 3,263 & 24 & 547 \\
\hline Chrl I:42I 26777-46489372 & $4,362,596$ & $1,560,848$ & $q A 5-q B I . I$ & 5,120 & 49 & 547 \\
\hline Chrll:I01602336-121653288 & $20,050,953$ & $6,694,702$ & qD-qE2 & 24,413 & 584 & 547 \\
\hline ChrI7:7177|954-72520788 & 748,835 & 344,281 & $\mathrm{qE} 2$ & 740 & 7 & 547 \\
\hline Totals & $31,846,164$ & I I ,094,2 I 6 & & 37,929 & 671 & \\
\hline Chr7:1-141,766,352 & $|4|, 766,352$ & $58,864,541$ & & 2,900 & & 28,587 \\
\hline Chr8:I-127,874,053 & $127,874,053$ & $48,159,999$ & & 2,090 & & 38,141 \\
\hline Print Controls & & & & 1,370 & & \\
\hline Totals & & & & 44,289 & & \\
\hline
\end{tabular}


Blocking Agent, and Agilent Hybridization Buffer (Agilent, 5188-5226). Hybridization took place in a rotisserie oven set to $65^{\circ} \mathrm{C}$ with a rotation speed of $20 \mathrm{rpm}$. The washing and scanning of the slides was performed in an ozone-free area to prevent the degradation of the cyanine 5 dye. Each slide was washed according to the manufacturer's recommendations with no Stabilization and Drying Solution. The slides were scanned on an Agilent DNA Microarray Scanner B.

TIFF image files generated from the scanner were analyzed using Agilent's Feature Extraction Software 8.1. This software allows a standardized method of extracting data using a standard CGH normalization protocol based on all array features (44k_CGH_0605). The QC report generated was checked to ensure proper hybridization and placement of the grid by the software. Data generated by the Feature Extraction tool were loaded into CGH Analytics 3.1 (Agilent Technologies) to allow visualization of the data. Dye swap pairs were combined to facilitate the visualization of chromosomal aberrations. A smoothing average of $50 \mathrm{MB}$ was used for the full genome arrays. Regions of aberration (deleted or amplified) were determined by the methodology of Barrett et al.[19].

\section{Gene expression}

Total RNA extraction and biotin-labeled probe synthesis for gene expression analysis has been described previously $[11,12]$. Frozen tissues from MIN-O lines $4 \mathrm{w}-4(\mathrm{n}=3$ MIN-Os, $\mathrm{n}=3$ tumors), $4 \mathrm{w}-11$ ( $\mathrm{n}=3$ MIN-Os, $\mathrm{n}=3$ tumors), $8 \mathrm{w}-\mathrm{B}$ ( $\mathrm{n}=4$ MIN-Os, $\mathrm{n}=4$ tumors) and $8 \mathrm{w}-\mathrm{D}$ ( $\mathrm{n}$ $=4$ MIN-Os, $\mathrm{n}=3$ tumors) and intact mammary fat pads from 16-day prelactating FVB females $(\mathrm{n}=2)$ were used for hybridization onto Murine Genome U74Av2 GeneChips (Affymetrix, Santa Clara, CA). The scanned images were processed using GCOS 1.4, and then the data was analyzed with GC-RMA in the ArrayAssist software package (Stratagene). GCRMA derived expression values were log-transformed and analyzed in Arrayassist (t-test, unequal variance). Expression comparisons of all MIN-Os to prelactating mammary glands, and all tumors to MIN-Os were carried out in Arrayassist using t-test with FDR correction. 938 probes were differentially expressed with $\mathrm{p}<$ 0.01 in the MIN-Os vs prelactating comparison. 55 probes were differentially expressed with $\mathrm{p}<0.01$ in the tumors vs MIN-Os comparison. For expression comparisons of samples from individual lines, profiles were compared in Arrayassist using t-test without FDR correction and gene lists were generated with criteria of $\mathrm{p}<0.01$.

Gene lists were subjected to pathway and function analysis in Ingenuity Pathways Analysis (Ingenuity Systems, Redwood City, CA). Annotation and gene ontology of each probe was assigned by NetAffyx (Affymetrix, Inc). The results from the statistical analyses described above were analyzed by ErmineJ software [20] to determine the number of significant gene ontology (GO) categories using gene score resampling (GSR) [21]. Unfiltered t-test results were imported into Erminej and analyzed using a 100,00 fold iteration re-sampling approach to determine which Biological Processes categories were significant below a Benjamini-Hochberg FDR-corrected p-value of 0.01 .

For correlating the genomic changes to the expression differences, chromosome locations of probes and known genes were determined by the UCSC Genome Browser [22]. For the analysis of whole chromosome gain of chromosome 2, expression values of chromosome 2 probes ( $\mathrm{n}$ $=871$ ) from $8 \mathrm{w}-\mathrm{B}$ and $4 \mathrm{w}-4$ MIN-Os were compared to those from $8 \mathrm{w}-\mathrm{D}$ and $4 \mathrm{w}-11 \mathrm{MIN}-\mathrm{Os}$ (t-test, unequal variance). For chromosome 1, 10 and 11 probes $(\mathrm{n}=652$, 481 , and 957, respectively), expression values from $8 \mathrm{w}-\mathrm{B}$ MIN-Os were compared to those from $8 \mathrm{w}-\mathrm{D}, 4 \mathrm{w}-4$, and $4 \mathrm{w}-11$ (t-test, unequal variance). For the analysis of $2 \mathrm{~F}$, $3 \mathrm{E}, 17 \mathrm{E}$ and $11 \mathrm{~B}$, the corresponding probes were identified in UCSC Genome Browser. For $2 \mathrm{~F}, 3 \mathrm{E}$ and $17 \mathrm{E}$ probes, the average expression values of the $8 \mathrm{w}$-D MIN-Os were compared to the average expression values of $8 \mathrm{w}-\mathrm{B}$, $4 \mathrm{w}-4$ and $4 \mathrm{w}-11 \mathrm{MIN}-\mathrm{Os}$. For 11B probes, expression values of the 5189 MIN-O sample were compared to those of the $5207 \mathrm{MIN}-\mathrm{O}$ sample.

\section{Results \\ MINs are heterogeneous}

Each transplantable MIN-O mouse line was established from an individual MIN lesion from a $\operatorname{Tg}(P \gamma V m T)$ mammary fat pad. Each line has characteristic phenotypes (Table 2), as previously described [11]. Distinct histological features have been maintained in each MIN-O line over multiple transplant generations. Detailed histological analysis of MIN-O and tumor tissues from each MIN$\mathrm{O}$ line has been published previously [11]. The metastatic potential of each MIN-O line is also different: $8 \mathrm{w}$-D and $4 \mathrm{w}-11$ MIN-Os are considered metastatic lines, while $8 \mathrm{w}-$ $\mathrm{B}$ and $4 \mathrm{w}-4$ are non-metastatic lines.

\section{Ovarian hormone sensitivity of MIN-Os}

ER status and ovarian hormone dependence is an important diagnostic factor for mammary lesions. In general, early mammary lesions developed in $\operatorname{Tg}(P \gamma V m T)$ mammary fat pads are ER-positive, but the expression of ER is lost as the lesions progress to invasive carcinoma [23]. Previously, we showed that the MIN-O from the $8 \mathrm{w}-\mathrm{B}$ mouse line was ER-positive and also that MIN-O growth was ovarian hormone-dependent, while the tumors derived from the $8 \mathrm{w}$-B MIN-O express significantly less ER [15]. Since each MIN-O line represents individual mammary lesions from $\operatorname{Tg}(\mathrm{PyVmT})$ fat pads that have distinct characteristics, we tested the ovarian hormone depend- 
Table 2: Characteristics of MIN-O lines

\begin{tabular}{|c|c|c|c|}
\hline MIN-O line & Major histological characteristics of MIN-Os* & Metastasis Index* & ER status of MIN-Os \\
\hline $4 w-4$ & Solid chords \& nests & 0 & Negative or cytoplasmic \\
\hline $4 w-11$ & Microacini \& organized cysts & 0.63 & Mostly cytoplasmic \\
\hline $8 w-B$ & Dysplastic cysts. Better differentiated. Microacinar structures. & 0 & Nuclear (+++) \\
\hline $8 w-D$ & Prominent and distinct microacinar patterns. Organized cysts. Patches of eosinophilic microacini. & 0.47 & Nuclear (+) \\
\hline
\end{tabular}

* From Maglione et al 2004.

ence of the MIN-O lines by transplanting each to the fat pads of ovariectomized host females (Table 3). Ovarian ablation decreased the average MIN-O size and delayed palpable tumor development, but with various degrees of statistical significance in each line. In particular, ovariectomy significantly inhibited both the MIN-O growth and tumor latency in the $8 \mathrm{w}$-B and $8 \mathrm{w}$-D mice, while only the MIN-O growth was significantly affected in the $4 \mathrm{w}-4$ mice. In the $4 \mathrm{w}-11$ mice, the ovariectomy reduced the averaged MIN-O size and increased tumor latency, but the effects were not statistically significant. On the other hand, when tumors that developed in ovary-intact MIN-O mice were transplanted to ovariectomized hosts, the ovariectomy did not inhibit tumor growth significantly in any of the lines (data not shown). This demonstrates that the growth of the tumors that have developed from the MIN-Os is not dependent on ovarian hormones while the growth of the MIN-Os is sensitive to the levels of these hormones.

ER expression in the $4 \mathrm{w}-4,4 \mathrm{w}-11,8 \mathrm{w}-\mathrm{B}$ and $8 \mathrm{w}-\mathrm{D}$ MINOs were determined by immunohistochemistry of the MIN-O transplanted fat pads (Table 2). In the intact hosts, patches of strong nuclear ER-positive cells were present in the $8 \mathrm{w}$-B MIN-Os, while in the $8 \mathrm{w}-\mathrm{D}$ MIN-Os, nuclear ERpositive cells were also present, but with less intensity. In 4w-4 and 4w-11 MIN-Os from the intact hosts, nuclear ER staining was rarely found and, if any, weak ER staining was seen in the cytoplasm. In all four lines, MIN-Os from the ovariectomized hosts had no nuclear ER-positive cells, and reduced cytoplasmic staining, if any, compared to those from the intact hosts (data not shown).

\section{CGH analysis}

To study genomic aberrations associated with MIN-O and tumor samples, we utilized Agilent mouse CGH arrays on $14 \mathrm{MIN}-\mathrm{O} /$ tumor pairs. Genomic DNA from at least 3 different MIN-Os and the corresponding tumors from the same fat pad were isolated from 4 different MIN-O mouse lines.

Nine out of 14 MIN-Os carried some type of whole chromosome gain (Figure 1B). The most common chromosome aberration was whole chromosome gain of chromosome $2(50 \%)$, followed by chromosome 11 $(28.6 \%), 1(28.6 \%)$, and $10(21.4 \%)$. The corresponding tumor samples carried the same chromosome gain(s), except for one pair. Some of the tumors had acquired additional genomic changes, suggesting that these changes occurred during the MIN-O to tumor transition (Figure 1C). The most common gain associated with the tumor transformation was the whole chromosome gain of chromosome 15 (4 out of 14 tumors) (Figure 1D). Other whole chromosome gains associated with the progression to tumor were found for chromosome 5, 6, 11, and 13 (1 out of 14 tumors, each). $36 \%$ (5/14) of the MIN-Os had no major genomic abnormalities.

In addition to the whole chromosome gains, the MIN-Os also exhibited chromosomal losses and/or gains of small chromosomal regions. The most common regions deleted were $2 \mathrm{~F} 1-2$ (21.4\% MIN-Os and tumors), 3E4 (7.1\% MIN-Os, $21.4 \%$ tumors), and 17E2 (7.1\% MIN-Os, $21.4 \%$ tumors). Other regions that were found to have deletions in one MIN-O/tumor pair were $12 \mathrm{~A}, 16 \mathrm{C} 2$, and

Table 3: Effect of ovariectomy on MIN-O growth and tumor latency

\begin{tabular}{|c|c|c|c|c|c|c|c|}
\hline \multirow[t]{3}{*}{ MIN-O line } & \multicolumn{4}{|c|}{ MIN-O size at 5-weeks posttransplantation } & \multicolumn{3}{|c|}{ Tumor latency (in weeks) } \\
\hline & \multirow[b]{2}{*}{ Control \%FPF (n) } & \multicolumn{2}{|c|}{ Ovx } & \multirow[b]{2}{*}{ p-value } & \multirow[b]{2}{*}{ Control $\mathrm{TE}_{50}$} & \multirow[b]{2}{*}{ Ovx $\mathrm{TE}_{50}$} & \multirow[b]{2}{*}{ P-value } \\
\hline & & $\% \operatorname{FPF}(n)$ & relative to control & & & & \\
\hline $4 w-4$ & $55.00 \pm 10.00(4)$ & $24.29 \pm 9.76(7)$ & 0.44 & 0.0008 & 10.1 & $>10.1$ & 0.113 \\
\hline $4 w-11$ & $37.50 \pm 17.08(4)$ & $15.00 \pm 18.17(6)$ & 0.40 & 0.08 & 10.2 & 12.1 & 0.118 \\
\hline $8 w-B^{*}$ & $67.50 \pm 12.58(4)$ & $22.86 \pm 7.56(7)$ & 0.34 & $<0.0001$ & 4.9 & 11.1 & 0.002 \\
\hline $8 w-D$ & $60.00 \pm 0.00(4)$ & $10.71 \pm 4.50(7)$ & 0.18 & $<0.0001$ & 8.15 & 12.1 & 0.017 \\
\hline
\end{tabular}

* from Namba et al 2005 
A

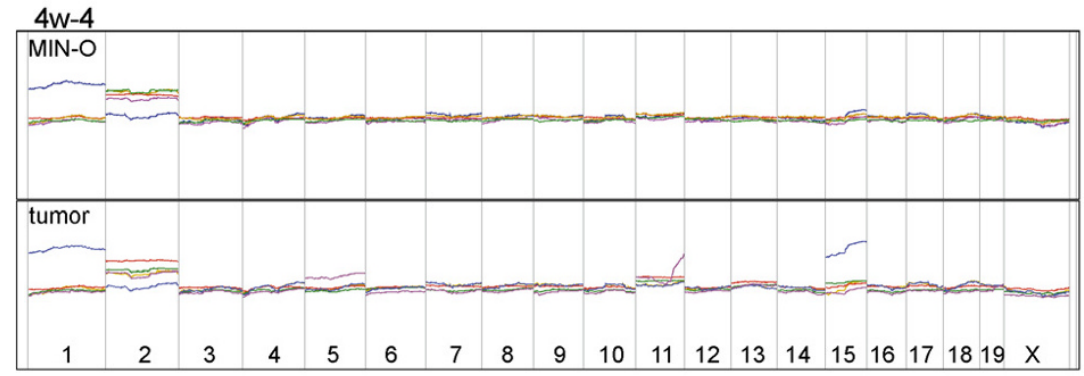

$4 \mathrm{w}-11$

MIN-O
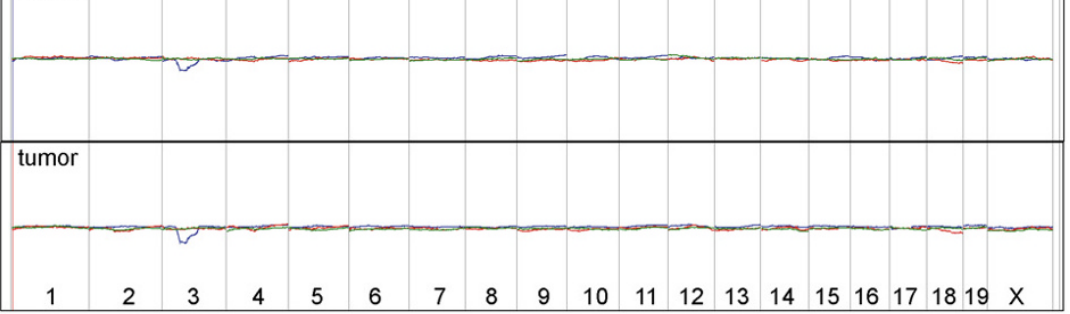

$8 w-B$

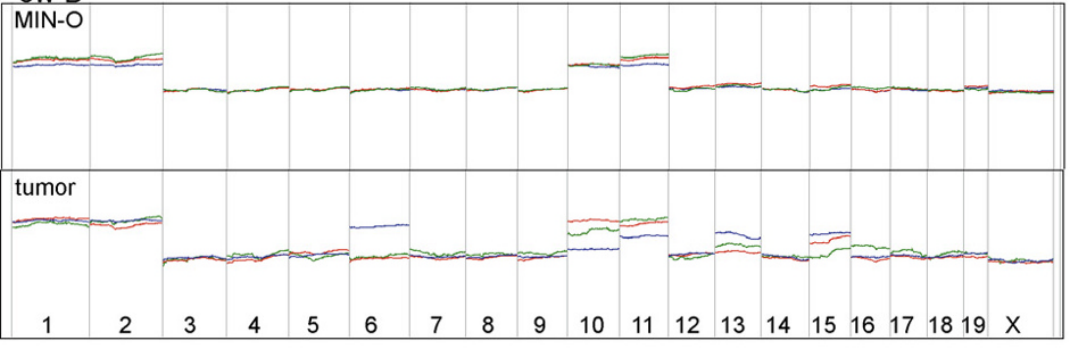

$8 w-D$

MIN-O

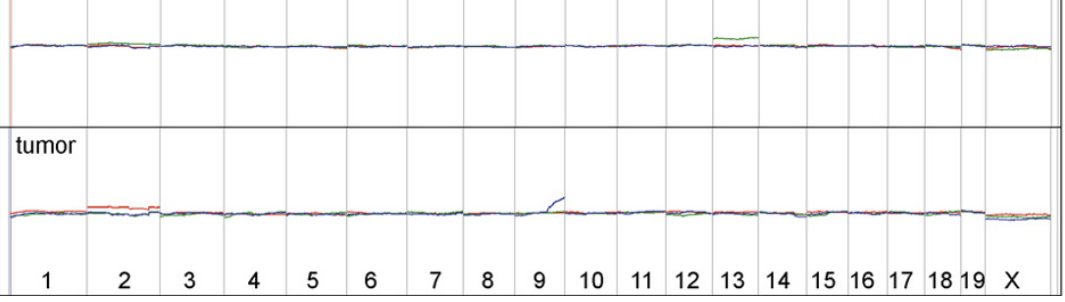

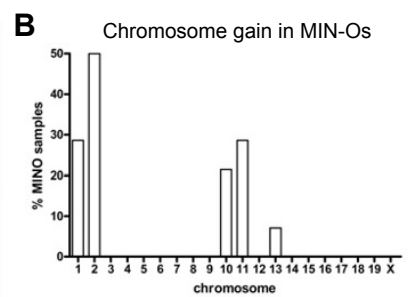

C Chromosome gain in tumors

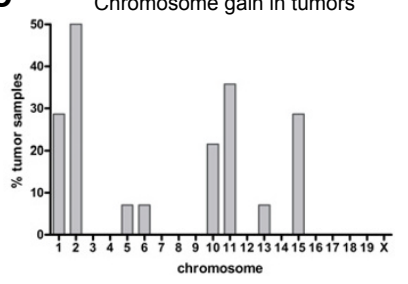

D Chromosome gain
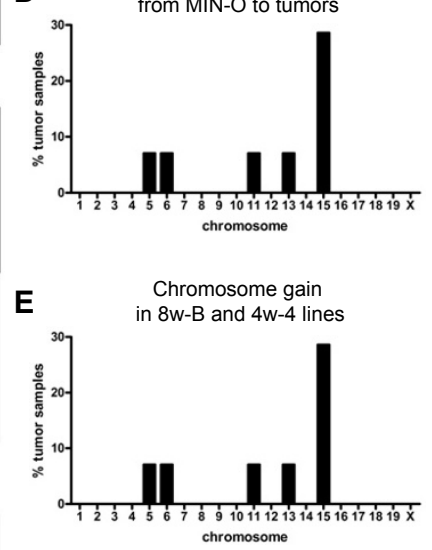

Figure I

Mouse whole genome CGH microarray data from MIN-Os and tumors. A) Summary of array CGH data by MIN-O lines. Agilent mouse whole genome CGH microarray was used for genomic DNA from different MIN-O and tumor pairs from $4 \mathrm{w}-4,4 \mathrm{w}-\mathrm{II}$, 8w-B and 8w-D MIN-O mice. The graphs were generated with a smoothing average of $50 \mathrm{MB}$. Each Pair of MIN$O$ and corresponding tumor from the same animal is represented with the same color $(n=4$ for $4 w-4, n=3$ each for $4 w-I I$, $8 w-B$ and $8 w-D$ ). $4 w-4$ and $8 w-B$ samples have multiple whole chromosome gains. $4 w-I I$ and $8 w-D$ samples are relatively genetically stable. B-E) Frequency of whole chromosome gains found in MIN-Os and tumors by array CGH. B) Distribution of whole chromosome gains in all MIN-Os studied with array CGH $(n=14)$. The most frequent gain is found on chromosome 2, followed by chromosome I and II. C) Distribution of chromosome gains in all tumor samples studied with array CGH $(\mathrm{n}=$ 14). Tumors have the same whole chromosome gains found in MIN-Os with a few additional gains. D) Frequency of whole chromosome gain events associated with MIN-O to tumor transition. Whole chromosome gains in tumors that are not found in the corresponding MIN-O samples are presumed to be acquired during the transition from MIN-O to tumor. E) Frequency of chromosome gains in $8 w-B$ and $4 w-4$ samples ( $n=8$ for MIN-Os and tumors each). The majority of whole chromosome gains were found in the $8 w-B$ and $4 w-4$ MIN-O lines. 
3D-E1. Also, the deletion of a small region in 19D was found in a single tumor.

Small interstitial gains (duplication) of a chromosome material were not as common as interstitial chromosome deletions. The only recurring small gain was $11 \mathrm{~B} 1.2$ (7.1\% MIN-Os, $14.2 \%$ tumors). Another area of interest was duplication of 11E1 found in one tumor sample. This area has been reported to be amplified in $\operatorname{Tg}(\operatorname{PyVmT})$ tumors [24].

\section{Expression changes associated with tumorigenesis}

To understand the expression changes associated with mammary tumorigenesis, as well as the molecular basis of the heterogeneity of mammary lesions, we studied gene expression profiles of MIN-Os and tumor samples. Highly proliferative wild-type mammary gland (prelactating) was used as the control, as it has the same proliferative index as the early preneoplastic tissue (in contrast to the nonproliferative quiescent mammary fat pad). The tissues were analyzed with the Affymetrix GeneChip MG-U74Av2 oligonucleotide arrays.

The gene expression profiles of the MIN-Os were dramatically different from that of the proliferating mammary glands. 937 probes (899 genes - comprised of 19 unknown probes, 103 unknown genes or ESTs, and 777 known genes) were differentially expressed $(p<0.01)$. 293 out of the 777 known genes were down-regulated in MIN-Os and 484 out of the 777 genes were over-expressed in MIN-Os. The majority of these genes were involved in cell cycle and/or cell death functions [see Additional file $1]$.

In general, the expression profiles of tumors were very similar to those of the MIN-Os. Only 55 probes (50 known genes) were differentially expressed $(p<0.01)$, and they were all down-regulated (Table 4). Nine of these genes are related to extracellular matrix (TNXB, SGCE, DPT, LUM, GSN, LAMA2, C1R, CLEC3B, DF, LPL, NID, RBP4, RETN); another set of noticeable genes are Igfbp-6 and PPP2R5a, which are anti-proliferative genes. Since many of these genes are known to be found in stroma, we examined the expression level of an epithelial marker, Krt2-8 (Keratin 8), in the samples to determine whether the expression changes are due to the change in the epithelial component of the tissues. Krt2-8 expression between the MIN-Os and tumors was not statistically significantly different ( $\mathrm{p}=0.1855$, t-test, $\mathrm{FC}=1.2)$. In previous studies, TaqMan quantitative PCR was utilized to confirm the expression of several genes (decorin, IGFBP2, Thrsp, Sncg, SerpinG1) in MIN-O and tumor pairs and showed that this data correlated with the direction and fold change of the microarray data [12]. In addition, immunohistochemistry studies demonstrated that the gene expression differences are not due to differences in the epithelial and stromal abundance in the MIN-O and tumor but rather due to inherent differences in the tissues. Thus, it is unlikely that the significant down-regulation of these 50 genes in the tumors is solely due to the enrichment of the stroma in the MIN-Os.

\section{Molecular changes associated with each MIN-O line Recurring genomic aberration by MIN-O lines}

When CGH results were analyzed for each MIN-O line, we found recurring genomic changes that were specific to certain lines. MIN-Os from $8 \mathrm{w}-\mathrm{B}$ and $4 \mathrm{w}-4$ mice carried large chromosome aberrations, frequently including multiple chromosome gains, while large chromosome aberrations were rare in the $4 \mathrm{w}-11$ and $8 \mathrm{w}-\mathrm{D}$ lines (Figure $1 \mathrm{~A} \& \mathrm{E}$ ). $100 \%$ of $8 \mathrm{w}-\mathrm{B}$ MIN-Os carried whole chromosome gain of chromosomes 1, 2, 10 and $11.80 \%$ of $4 \mathrm{w}-4 \mathrm{MIN}-\mathrm{Os}$ carried whole chromosome gain of chromosome 2 . Tumors arising from both MIN-O lines ( $8 \mathrm{w}-\mathrm{B}$ and $4 \mathrm{w}-4)$ often acquired additional chromosome gain(s) ( 6 out of 8 tumors), although the majority of the cases were limited to a gain of one chromosome, and there were no recurring chromosome gains found in tumors, except for chromosome 15.

In the MIN-O lines with whole chromosome gains, the gene expression pattern reflected the genomic changes. When expression of genes on chromosome 2 from the MIN-O lines with whole chromosome gains $(8 \mathrm{w}-\mathrm{B}$ and $4 \mathrm{w}-4)$ were compared to those from the lines with normal chromosome number ( $4 \mathrm{w}-11$ and $8 \mathrm{w}-\mathrm{D}), 60$ probes had significantly higher expression $(\mathrm{p}<0.01)$ in $8 \mathrm{w}-\mathrm{B}$ and $4 \mathrm{w}-$ 4 MIN-Os, while only 5 probes had significantly lower expression, when compared to $4 \mathrm{w}-11$ and $8 \mathrm{w}-\mathrm{D}$ MIN-Os (Table 5). For chromosomes 1, 10 and 11, which were gained in $8 \mathrm{w}-\mathrm{B}$ MIN-Os, genes on these chromosomes had higher expression in $8 \mathrm{w}-\mathrm{B}$ MIN-Os compared to the rest of the MIN-Os (Table 6).

In-depth analysis of the data found that all the $8 \mathrm{w}$-D samples carried deletions of 2F1-2, 3E4, and 17E2 regions. A pair of MIN-O and tumor samples from one $8 \mathrm{w}$-D animal (5189) had the same amplification of 11B1 region. We also found a large amplification of $11 \mathrm{E}$ in a tumor from one $4 \mathrm{w}-4$ animal. Among the four MIN-O lines, we found the least amount of chromosome abnormality in $4 \mathrm{w}-11$ samples. $4 \mathrm{w}-11$ samples did not carry any whole chromosome aberrations, or large duplications. In one MIN-O/ tumor pair of $4 \mathrm{w}-11$, we found a small deletion in the 3DE1 region.

\section{Zoom-in arrays}

To confirm the small deletions and duplications detected by the whole genome arrays, a custom CGH array for the $11 \mathrm{~B}, 11 \mathrm{E}, 2 \mathrm{~F}, 3 \mathrm{E}$, and $17 \mathrm{E}$ regions was designed (see mate- 
Table 4: Tumor vs MIN-O expression differences

\begin{tabular}{|c|c|c|c|c|}
\hline Probe Set ID & Gene Title & Gene Symbol & FC in tumors & GO biological function \\
\hline 99104_at & adiponectin, $\mathrm{CIQ}$ and collagen domain containing & Adipoq & -21.75 & $\begin{array}{l}\text { Lipid metabolism, Organic acid } \\
\text { metabolism }\end{array}$ \\
\hline 9967I_at & adipsin & Adn & -35.98 & \\
\hline 98924_at & ADP-ribosyltransferase 3 & Art3 & -2.55 & \\
\hline 92537_g_at & adrenergic receptor, beta 3 & Adrb3 & -2.88 & \\
\hline 102327_at & amine oxidase, copper containing 3 & Aoc3 & -3.66 & Cell adhesion \\
\hline 96785_at & ankyrin repeat domain 47 & Ankrd47 & -2.04 & \\
\hline 10476I_at & anthrax toxin receptor 2 & Antxr2 & -1.60 & \\
\hline 160375_at & carbonic anhydrase 3 & Car3 & -20.83 & \\
\hline 101539_f_at & carboxylesterase 3 & Ces3 & -4.06 & $\begin{array}{l}\text { Lipid metabolism, Organic acid } \\
\text { metabolism }\end{array}$ \\
\hline 102016_at & cell death-inducing DFFA-like effector c & Cidec & -4.79 & \\
\hline 954I5_f_at & complement component $\mathrm{I}, \mathrm{r}$ subcomponent & $\mathrm{Clr}$ & -2.64 & \\
\hline 92224 at & C-type lectin domain family 3 , member b & Clec3b & -5.87 & \\
\hline 96346_at & cysteine dioxygenase I, cytosolic & Cdol & -9.76 & Organic acid metabolism \\
\hline 93996_at & cytochrome P450, family 2 , subfamily e, polypeptide I & Cyp2el & -3.54 & \\
\hline 96742_at & dermatopontin & Dpt & -5.06 & Cell adhesion \\
\hline 103031 g_at & dynamin I & Dnml & -2.21 & \\
\hline 92535_at & early B-cell factor I & Ebfl & -1.81 & \\
\hline 100567_at & fatty acid binding protein 4 , adipocyte & Fabp4 & -2.31 & \\
\hline 9244I_at & fibroblast activation protein & Fap & -2.27 & \\
\hline 101991_at & flavin containing monooxygenase I & Fmol & -3.20 & \\
\hline 93040_at & FXYD domain-containing ion transport regulator I & Fxydl & -2.69 & \\
\hline 93750_at & gelsolin & Gsn & -5.43 & \\
\hline 102373_at & glutamyl aminopeptidase & Enpep & -2.86 & \\
\hline 99108_s_at & growth hormone receptor & Ghr & -1.99 & \\
\hline 92833_at & histidine ammonia lyase & $\mathrm{Hal}$ & -2.25 & Organic acid metabolism \\
\hline 95546_g_at & insulin-like growth factor I & $|g f|$ & -2.07 & \\
\hline 103904_at & insulin-like growth factor binding protein 6 & Igfbp6 & -4.34 & \\
\hline 92366_at & laminin, alpha 2 & Lama2 & -3.25 & Cell adhesion \\
\hline 103083_at & lipase, hormone sensitive & Lipe & -2.46 & Lipid metabolism \\
\hline 160083_at/956II_at & lipoprotein lipase & Lpl & -5.18 & Lipid metabolism \\
\hline 93353_at & lumican & Lum & -9.33 & \\
\hline 97520_s_at & neuronatin & Nnat & -5.92 & \\
\hline 100120_at & nidogen I & Nidl & -2.19 & Cell adhesion \\
\hline 16048I_at & phosphoenolpyruvate carboxykinase I, cytosolic & Pckl & -2.61 & $\begin{array}{l}\text { Lipid metabolism, Organic acid } \\
\text { metabolism }\end{array}$ \\
\hline 102763_at & plasma membrane associated protein, S3-12 & MGI:1929709 & -8.13 & \\
\hline 93826_at & protein phosphatase 2 , regulatory subunit $B(B 56)$, alpha isoform & Ppp2r5a & -1.43 & \\
\hline 102366_at & resistin & Retn & -10.89 & \\
\hline 97835_at & retinoic acid receptor responder (tazarotene induced) 2 & Rarres2 & -6.19 & \\
\hline 96047_at & retinol binding protein 4 , plasma & Rbp4 & -4.08 & \\
\hline 104445_at & RIKEN cDNA 463I4080II gene & 463 I408OIIRik & -5.20 & \\
\hline 10186I_at & sarcoglycan, epsilon & Sgce & -1.62 & \\
\hline 102707_f_at & serine (or cysteine) peptidase inhibitor, clade $A$, member $3 C$ & Serpina3c & -1.94 & \\
\hline 97429_at & SNF related kinase & Snrk & -1.65 & \\
\hline 92582_at & solute carrier family I (neutral amino acid transporter), member 5 & Slcla5 & -1.94 & \\
\hline 160320_at & sorbin and $\mathrm{SH} 3$ domain containing I & Sorbs I & -2.74 & Cell adhesion \\
\hline 94056_at/94057_g_at & stearoyl-Coenzyme A desaturase I & Scdl & -2.76 & $\begin{array}{l}\text { Lipid metabolism, Organic acid } \\
\text { metabolism }\end{array}$ \\
\hline 103087_at & sulfotransferase family IA, phenol-preferring, member I & Sultlal & -1.68 & Lipid metabolism \\
\hline 103568_at & sushi-repeat-containing protein & Srpx & -2.84 & \\
\hline 104280_at & synuclein, gamma & Sncg & -4.63 & \\
\hline 102916_s_at/161907_s_at & tenascin $X \mathrm{~B}$ & $\operatorname{Tn} \times b$ & -4.73 & Cell adhesion \\
\hline 160547_s_at & thioredoxin interacting protein & Txnip & -2.83 & \\
\hline 99052_at & zinc finger homeobox la & Zfhxla & -1.63 & \\
\hline
\end{tabular}

rials and methods). With this "zoom-in" array, we were able to more finely map the deleted regions in the $8 \mathrm{w}-\mathrm{D}$ samples as follows: $111 \mathrm{~kb}$ on $2 \mathrm{~F} 1-2$ (chr2: 130,621,986$131,735,939), 383 \mathrm{~kb}$ on 3E4 (chr3: 83,909,58684,292,657), $59 \mathrm{~kb}$ on 17E2 (chr17: 72,077,340$72,137,044)$ (Figure 2). The genes in these regions are: Hspa12b, 1700037H04Rik, Spef1, Cenpb, cdc25b, 2310035K24Rik, D430028G21Rik, Pank2, Rnf24, Smox,
Adra1d, 1600014E20Rik, Prnp, Rassf2, Slc23a2, on chromosome 2; Trim2, 6330505N24Rik, on chromosome 3; and 2810410M20Rik on chromosome 17. 10 out of 16 genes in the deleted region on chromosome 2 are represented on the 74Av2 array by 10 probes (Table 7). In 6 out of the 10 probes, the average expression in the $8 \mathrm{w}$-D MINOs was lower as compared to the MIN-Os from other lines (Table 7). The deleted regions in $3 \mathrm{E}$ and $17 \mathrm{E}$ were covered 
Table 5: Chromosome 2 gene expression in MIN-O lines with whole chromosome gains (8w-B \& 4w-4 vs. 8w-D \& 4w-I I)

\begin{tabular}{ccccc}
\hline & P-value & increased & $\begin{array}{c}\text { \# of probes } \\
\text { decreased }\end{array}$ & total probes \\
\hline Chr 2 & $<0.01$ & 60 & 5 & 871 \\
& $<0.05$ & 143 & 15 & 8 \\
\hline
\end{tabular}

by only one probe each (104207_at for 6330505N24 and 98886_at for 2810410M20Rik). The expression of both genes was lower in $8 \mathrm{w}$-D MIN-Os compared to the other MIN-Os.

The detailed breakpoints of the two duplicated regions (11B and 11E) were confirmed by the zoom-in array. The breakpoints on 11qB were 42,631,278-44,744,905, which spanned the following genes: Pttg1, D11Ertd730e, C1qtnf2, Fabp6, Ttc1, Adra1b, Il12b, Ublcp1, 3732413I11Rik, Ebf1 (Table 8). These genes are represented by 11 probes on the 74Av2 array, and the expression of these genes in the 5189 MIN-O (the $8 \mathrm{w}-\mathrm{D}$ MIN-O sample with the $11 \mathrm{~B}$ amplification) are higher than in the 5207 MIN-O (an 8w-D MIN-O without the amplification). The $11 \mathrm{qE} 1$ region seems to be comprised of regions with varying degrees of amplification, starting from $102,146,284$ to the end $(121,647,795)$ (data not shown). In general, the interstitial aberrations identified show concomitant gene expression changes and suggest that there is a DNA dosage-gene expression relationship.

Gene expression associated with each MIN-O line

Since each MIN-O line has distinct biological characteristics, we expected to find unique gene expression features for each line. To identify unique expression changes associated with each MIN-O lines, we subjected each list of MIN-O vs. PL differences to GSR GO analysis. There were only 5 significant GO biological function terms $(\mathrm{p}<0.05)$ in the $4 \mathrm{w}-4$ line (DNA-dependent DNA replication, chromatin assembly or disassembly, nucleosome assembly, regulation of cyclin dependent protein kinase activity, organic acid biosynthesis), of which the first four functions were significant in the other lines (Table 9). The $4 \mathrm{w}$ 11 line was characterized by three highly significant I-kap-
paB/NF-kappaB pathway-related functions ( $\mathrm{p}<0.0001$ ) (Table 10). The cell cycle and mitotic spindle/microtubule related functions were particularly highly represented in $8 \mathrm{w}$-B line (Table 11). The $8 \mathrm{w}$-D line had over-representation of specific signaling pathways (Wnt, Ras and MAPK), as well as ECM-related functions (Table 12). Moreover, certain functions were common in multiple MIN-O lines. The immune response-related functions, as well as the IkappaB/NF-kappaB cascade related functions, were very highly represented in the $4 \mathrm{w}-11$ and $8 \mathrm{w}$-D lines. The functions related to UV light/radiation response were highly significant in the $4 \mathrm{w}-11$ and $8 \mathrm{w}-\mathrm{D}$ lines. $8 \mathrm{w}-\mathrm{B}$ and $8 \mathrm{w}-\mathrm{D}$ lines shared angiogenesis and steroid biosynthesis related functions as highly significant biological functions

Although the comparison of all tumors vs. all MIN-Os identified a small number of down-regulated genes, there was no one gene common to the tumor vs. MIN-O gene lists from the four MIN-O lines [see Additional file 2]. Because the expression profiles of tumors were very similar to the corresponding MIN-Os, GO analysis did not result in any significant functional terms. However each line had characteristic expression differences of genes that suggest changes in tumor-associated functions. Tumors developed from $4 \mathrm{w}-4$ MIN-Os were characterized by down-regulation of immunoglobulin and up-regulation of actin and myosin (3- to 4-fold change). Tnfrsf11/ RANK, receptor activator of NfאB [25], and RalA, which is a critical component for Ras-induced tumorigenesis [26] were also up-regulated in these tumors. In $4 \mathrm{w}-11$ tumors, CEBPA, which is associated with breast cancer progression [27] was down-regulated and CEBPB, a gene found to be up-regulated in breast cancer as well as mouse mammary tumors [28], is up-regulated. Moreover, the $4 \mathrm{w}-11$ tumors exhibited down-regulation of actin, myosin, Ig, and MHC

Table 6: Chromosome I, 10 and II gene expression differences in MIN-O lines with whole chromosome gains (8w-B vs. 8w-D, 4w-4 \& $4 w-I I)$

\begin{tabular}{ccccc}
\hline & P-value & increased & $\begin{array}{c}\text { \# of probes } \\
\text { decreased }\end{array}$ & total probes \\
Chr I & $<0.01$ & 78 & 11 & 652 \\
Chr I0 & $<0.05$ & 217 & 24 & 4 \\
Chr II & $<0.01$ & 61 & 14 & 481 \\
& $<0.05$ & 139 & 11 & 957 \\
\hline
\end{tabular}


$2 x$

chromosome 2

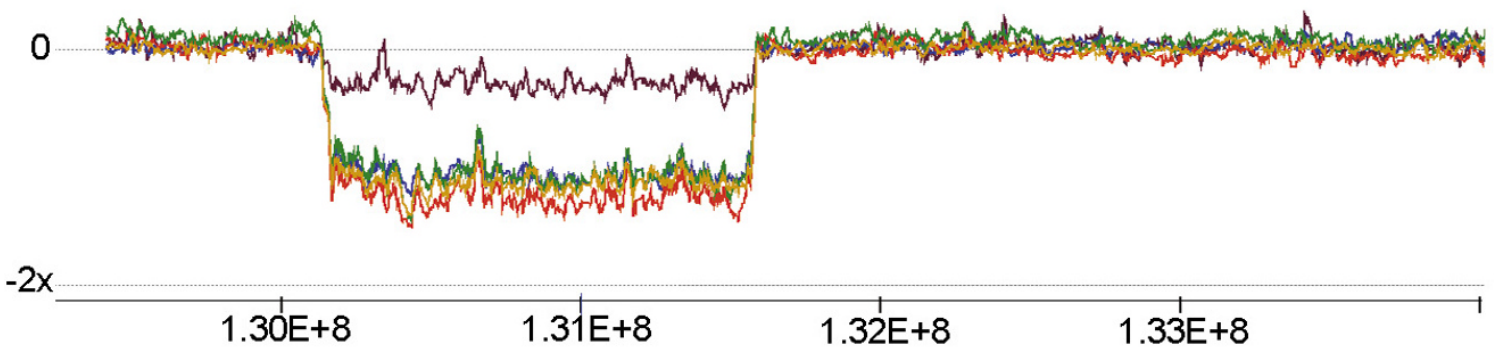

$2 x$

chromosome 3

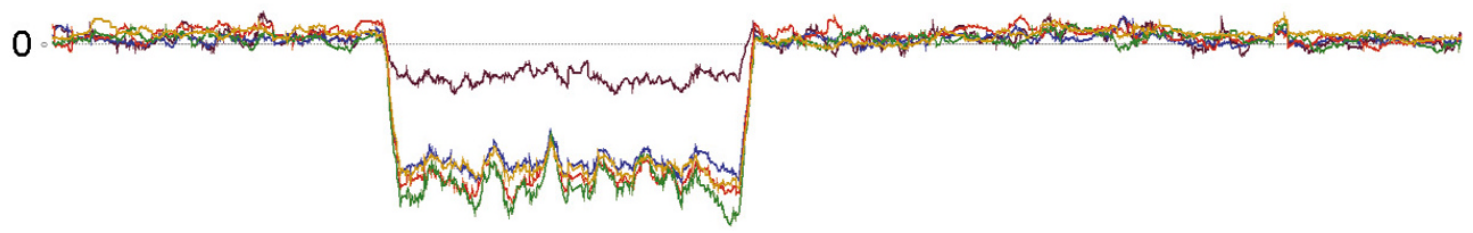

$-2 x$

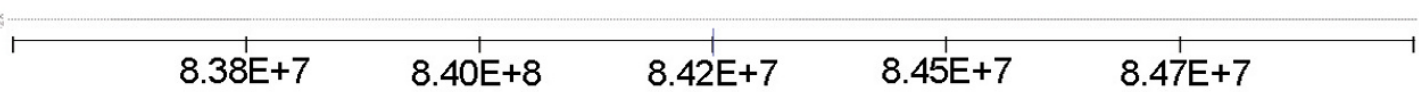

$2 x$

chromosome 17

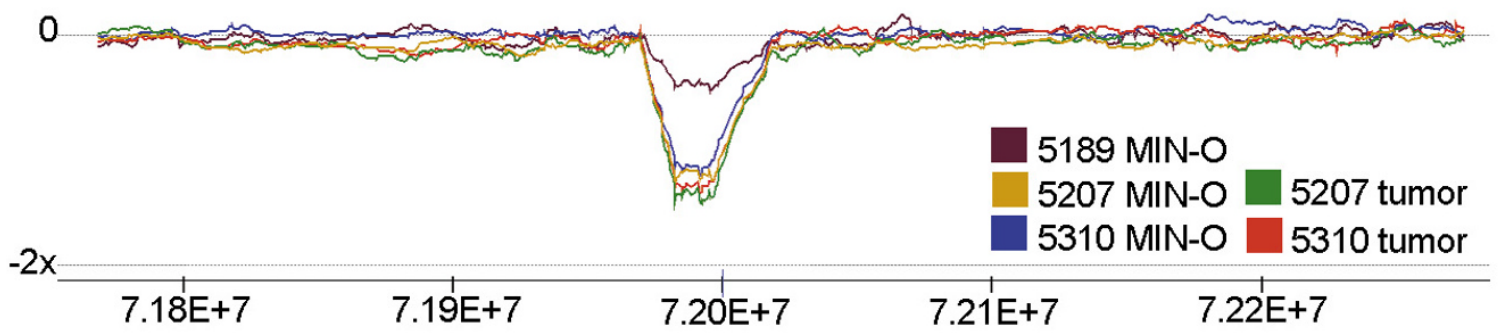

Figure 2

High resolution custom CGH microarray data on selected regions on chromosomes 2, 3 and I7. Small deletions in $2 \mathrm{~F}, 3 \mathrm{E}$, and I7E in MIN-Os and tumors from the $8 \mathrm{w}-\mathrm{D}$ line were confirmed with the custom designed "zoom-in" array with average spacing of $547 \mathrm{bp}$. The specific breakpoints were determined as follows: chr2:130,62I,986-131,735,939, chr3:83,909,586-84,292,657, chr17:72,077,340-72,137,044. 
Table 7: Expression in the deleted region (2FI-2, chr2: 130,62I,986-131,735,939)

\begin{tabular}{|c|c|c|}
\hline Genes & U74Av2 probe ID & lower expression in 8w-D MIN-Os* \\
\hline \multicolumn{3}{|l|}{ Hspa I2b } \\
\hline I 700037H04Rik & 97210_at & $x$ \\
\hline SpefI/493I426KI6Rik & 93475_at & $x$ \\
\hline Cenpb & 99486_at & $x$ \\
\hline $\mathrm{cdc} 25 \mathrm{~b}$ & 99012 at & \\
\hline 23I0035K24Rik & 96819_at & \\
\hline \multicolumn{3}{|l|}{ D430028G2IRik } \\
\hline \multicolumn{3}{|l|}{ Pank2 } \\
\hline Rnf24 & 97200_f_at & $x$ \\
\hline \multicolumn{3}{|l|}{ Smox } \\
\hline \multicolumn{3}{|l|}{ Adrald } \\
\hline I6000I4E20Rik & 161097_at & \\
\hline Prnp & 100606_at & $x$ \\
\hline \multicolumn{3}{|l|}{ Prnd } \\
\hline Rassf2 & 9477I_at & \\
\hline Slc23a2 & 104267_at & $x$ \\
\hline
\end{tabular}

* determined by $8 \mathrm{w}-\mathrm{D}$ MIN-Os compared to rest of the MIN-O samples

class 2 transcripts, which have been shown to be decreased in highly metastatic breast cancer cell lines [29], as well as decreased during progression to tumor [30]. 8W$B$ tumors had up-regulation of PLK [31] and 8w-D tumors had up-regulation of Epha2 [32].

\section{Molecular changes associated with biological characteristics}

Molecular changes in MIN-Os with genetic instability (lines $8 w-B$ and $4 w-4)$

dysregulation of mitotic spindle and chromosome segregation related genes To further understand the basis of chromosome instability in the MIN-Os, we assessed gene expression profiles of the genetically unstable MIN-O lines $-8 w-B$ and $4 w-4$. Seven out of eight MIN-O samples from these two lines had whole chromosome gain of chromosome 2 . The two lines had 13 genes from chromosome 2 in common in the gene expression comparison between MIN-O and PL [see Additional file 3]. Among these 13 genes, all but one was over-expressed in the MINOs. Aurora kinase A (Aurka/STK6/STK15) was the most dramatically over-expressed (9- to 10-fold).

Aurka regulates centrosome duplication and mitotic spindle assembly. Other genes involved in spindle assembly (Ran, Tuba1, Tubb6, Kif22, Nde1, Ndrg1) and centrosome duplication and sister chromatid segregation (Plk1, Gadd45a, Apc11, Cdc20 and Cdkn1a) were also dysregulated. In addition, genes up-regulated in $8 \mathrm{w}-\mathrm{B}$ and $4 \mathrm{w}-4$ $\mathrm{MIN}-\mathrm{Os}$ included a large group of E2F4 regulated genes (H2AFZ, RFC2, RFC4, ZNF305, KIF22, RPA3, RRM1, CDK4, CDC2, PLK1, PSMA4, and TK1) [33].

Expression profiles associated with metastatic MIN-Os

$8 \mathrm{w}-\mathrm{D}$ and $4 \mathrm{w}-11$ are the two MIN-O lines with highest metastatic index (Maglione 2004). From our GO analysis

Table 8: Expression in the duplicated region (I IB, ch I I:42,63 I,278-44,744,905)

\begin{tabular}{|c|c|c|}
\hline Genes & U74Av2 probe ID & higher expression in $5189 \mathrm{MINO} * *$ \\
\hline PttgI & 101026_at & $x$ \\
\hline \multirow[t]{2}{*}{ DIIErtd730e } & 160772_I_at & $x$ \\
\hline & 161428_at & $x$ \\
\hline \multicolumn{3}{|l|}{ Clqtnf2 } \\
\hline Fabp6 & 99977_at & $x$ \\
\hline \multirow[t]{2}{*}{ Ttcl } & $96921 \_$at & $x$ \\
\hline & 161887_r_at & $x$ \\
\hline Adralb & 92340_at & $x$ \\
\hline$I I I 2 b$ & 100779_at & $x$ \\
\hline Ublcpl & 94865_at & $x$ \\
\hline 37324I3IIIRik & 96104_at & $x$ \\
\hline Ebfl & 92535_at & $x$ \\
\hline
\end{tabular}

** determined by 5189 MIN-O compared to 5207 MIN-O 
Table 9: Significant biological functions for MIN-O vs PL expression differences for $4 \mathrm{w}-4$ line

\begin{tabular}{lll}
\hline Name & GO ID & Corrected P-value \\
\hline Highly significant GO functions & & \\
DNA-dependent DNA replication & GO:000626I & $0.00 \mathrm{E}+00$ \\
organic acid biosynthesis & GO:0016053 & $0.00 \mathrm{E}+00$ \\
chromatin assembly or disassembly & GO:0006333 & $0.00 \mathrm{E}+00$ \\
nucleosome assembly & GO:0006334 & $0.00 \mathrm{E}+00$ \\
regulation of cyclin dependent protein kinase activity & GO:0000079 & $2.68 \mathrm{E}-02$ \\
\hline
\end{tabular}

(Table 7), MIN-Os from both lines seem to have dysregulation of significant number of genes that are involved in immune-related responses and apoptotic program. The MIN-Os from these two lines share 209 probes that are dysregulated [see Additional file 4]. Among the 209 probes (186 genes and 18 ESTs), 42 genes are unique to these two lines. Examples of these unique genes include Serpine2, which is overexpressed in metastatic cancer; Ctnnb1, Fliih, Pdlim4/Ril, all of which affect migratory behavior of cells; and Gas6, which is a ligand for the Axl oncogene [34].

The metastasis signature genes in human cancer [35] have been reported to be predictive of a high metastatic rate in mouse tumors [36]. 14 out of these 17 signature genes are represented in the MG-U74Av2 array. We compared the expression of these 14 genes in both MIN-Os and tumors, between the two most metastatic MIN-O lines ( $8 \mathrm{w}$-D and
$4 \mathrm{w}-11)$ and the two least metastatic MIN-O lines ( $8 \mathrm{w}-\mathrm{B}$ and $4 \mathrm{w}-4)$. We did not find significant correlation of the expression trends between what has reported with human metastatic breast cancer and our metastatic MIN-O lines (data not shown), yet, further analysis and comparison to the human data is required in order to identify potential correlated GO terms and pathway hubs that may better reflect similarity in the model and the human data.

\section{Expression profiles associated with estrogen sensitivity}

$8 \mathrm{w}-\mathrm{B}$ and $8 \mathrm{w}-\mathrm{D}$ MIN-Os are more sensitive to ovarian ablation than other lines. Transcript levels of ERs in the $8 \mathrm{w}-\mathrm{B}$ and $8 \mathrm{w}-\mathrm{D}$ MIN-Os tend to be slightly higher than the $4 \mathrm{w}-4$ and $4 \mathrm{w}-11$ MIN-Os [see Additional file 5], which is consistent with ER expression found in the immunohistochemical analysis. Moreover, the expression of cyp19a1, an aromatase which catalyzes essential reactions for estrogen biosynthesis, is also slightly but statistically signifi-

Table I0: Significant biological functions for MIN-O vs PL expression differences for $4 \mathrm{w}-\mathrm{I}$ I line

\begin{tabular}{|c|c|c|}
\hline Name & GO ID & Corrected P-value \\
\hline \multicolumn{3}{|l|}{ I-kappB/NF-kappaB } \\
\hline regulation of I-kappaB kinase/NF-kappaB cascade & GO:0043I 22 & $0.00 \mathrm{E}+00$ \\
\hline positive regulation of I-kappaB kinase/NF-kappaB cascade & GO:0043I23 & $0.00 \mathrm{E}+00$ \\
\hline I-kappaB kinase/NF-kappaB cascade & GO:0007249 & $0.00 \mathrm{E}+00$ \\
\hline \multicolumn{3}{|l|}{ apoptotic program } \\
\hline apoptotic program & GO:0008632 & $0.00 \mathrm{E}+00$ \\
\hline \multicolumn{3}{|l|}{ Immune response } \\
\hline lymphocyte differentiation & GO:0030098 & 7.04E-03 \\
\hline antigen presentation, exogenous antigen & GO:0019884 & I.59E-02 \\
\hline xenobiotic metabolism & GO:0006805 & $2.02 \mathrm{E}-02$ \\
\hline T-cell activation & GO:0042110 & $2.72 \mathrm{E}-02$ \\
\hline response to xenobiotic stimulus & GO:0009410 & 2.68E-02 \\
\hline T-cell differentiation & GO:0030217 & 2.7IE-02 \\
\hline response to bacteria & GO:0009617 & 2.87E-02 \\
\hline regulation of immune response & GO:0050776 & $3.35 \mathrm{E}-02$ \\
\hline defense response to bacteria & GO:0042742 & 3.87E-02 \\
\hline antigen presentation & GO:0019882 & $4.2 \mathrm{IE}-02$ \\
\hline \multicolumn{3}{|l|}{ Reponse to radiation/UV } \\
\hline response to radiation & GO:00093।4 & 6.37E-03 \\
\hline phototransduction & GO:0007602 & I.53E-02 \\
\hline detection of light & GO:0009583 & I.91E-02 \\
\hline response to light & GO:00094I6 & 2.79E-02 \\
\hline
\end{tabular}


Table I I: Significant biological functions for MIN-O vs PL expression differences for $8 \mathrm{~W}-\mathrm{B}$ line

\begin{tabular}{|c|c|c|}
\hline Name & GO ID & Corrected P-value \\
\hline \multicolumn{3}{|l|}{ Spindle/Microtubule } \\
\hline mitotic spindle organization and biogenesis & GO:0007052 & $0.00 \mathrm{E}+00$ \\
\hline spindle organization and biogenesis & GO:000705 I & $0.00 \mathrm{E}+00$ \\
\hline microtubule cytoskeleton organization and biogenesis & GO:0000226 & $0.00 \mathrm{E}+00$ \\
\hline microtubule-based movement & GO:0007018 & 4.70E-07 \\
\hline chromosome segregation & GO:0007059 & $4.32 \mathrm{E}-03$ \\
\hline microtubule polymerization & GO:0046785 & I.59E-02 \\
\hline microtubule polymerization or depolymerization & GO:003II09 & I.97E-02 \\
\hline M phase specific microtubule process & GO:0000072 & $3.32 \mathrm{E}-02$ \\
\hline \multicolumn{3}{|l|}{ Cell cycle } \\
\hline regulation of mitosis & GO:0007088 & $0.00 \mathrm{E}+00$ \\
\hline cell cycle checkpoint & GO:0000075 & $0.00 \mathrm{E}+00$ \\
\hline interphase of mitotic cell cycle & GO:005I329 & $0.00 \mathrm{E}+00$ \\
\hline $\mathrm{GI} / \mathrm{S}$ transition of mitotic cell cycle & GO:0000082 & $0.00 \mathrm{E}+00$ \\
\hline negative regulation of cell cycle & GO:0045786 & $6.08 \mathrm{E}-03$ \\
\hline G2/M transition of mitotic cell cycle & GO:0000086 & I.29E-02 \\
\hline mitotic checkpoint & GO:0007093 & I.28E-02 \\
\hline regulation of cyclin dependent protein kinase activity & GO:0000079 & $1.25 \mathrm{E}-02$ \\
\hline GI phase of mitotic cell cycle & GO:0000080 & I.4IE-02 \\
\hline traversing start control point of mitotic cell cycle & GO:0007089 & I.67E-02 \\
\hline cell cycle arrest & GO:0007050 & I.67E-02 \\
\hline mitotic anaphase & GO:0000090 & $2.63 \mathrm{E}-02$ \\
\hline anaphase & GO:005I322 & $2.72 \mathrm{E}-02$ \\
\hline prophase & GO:005I324 & $2.8 \mathrm{IE}-02$ \\
\hline \multicolumn{3}{|l|}{ Angiogenesis } \\
\hline blood vessel morphogenesis & GO:00485I4 & $6.37 \mathrm{E}-03$ \\
\hline angiogenesis & GO:000I525 & I.0IE-02 \\
\hline blood vessel development & GO:000I568 & $9.73 \mathrm{E}-03$ \\
\hline \multicolumn{3}{|l|}{ Steroid } \\
\hline steroid biosynthesis & GO:0006694 & $3.45 \mathrm{E}-02$ \\
\hline
\end{tabular}

cantly higher in the $8 \mathrm{w}-\mathrm{B}$ and $8 \mathrm{w}-\mathrm{D}$ lines (fold change $=$ $1.07, \mathrm{p}=0.0068)$. In these lines, steroid biosynthesis $(\mathrm{p}=$ 0.0345 for $8 \mathrm{w}-\mathrm{B}, \mathrm{p}=3 \times 10^{-6}$ for $8 \mathrm{w}-\mathrm{D}$ ) and sterol metabolism ( $\mathrm{p}=0.0416$ for $8 \mathrm{w}-\mathrm{D}$ ) were represented as highly significant GO functions (Table 7). In addition, angiogenesis related functions were also significant. 271 probes (114 probes unique to only these two lines) were differentially expressed in both $8 \mathrm{w}-\mathrm{B}$ and $8 \mathrm{w}-\mathrm{D}$ MIN-Os [see Additional file 6]. Genes dysregulated only in $8 \mathrm{w}-\mathrm{B}$ and $8 \mathrm{w}$-D MIN-Os include proteins that interact with estrogen or ER, such as Abcg1, Gnai2, Fbln1, Nr4a1, Jun (all upregulated), and Strn and Cyp1b1 (both down-regulated). Also, NfкB pathway genes - Nfkb2, Relb, and Bcl10 were down-regulated.

\section{Discussion}

Major chromosome abnormalities associated with tumorigenesis are present at the MIN-O stage

This study is the first molecular analysis of mammary tumor progression in the four MIN-O mouse lines, and it shows that MIN-Os, mouse mammary premalignant lesions, are already genetically and molecularly advanced, with molecular and genomic profiles similar to those of invasive tumors. This study also confirms that these lesions, which originated in the same organ site, are genetically heterogeneous, as reflected from their morphologi$\mathrm{cal}$, genomic, and gene expression characteristics. We hypothesize that even with the same initiating oncogene, the resulting early premalignant lesions and subsequent tumors will have different groups of biologically distinct characteristics that are determined by the genetic changes already present in the early lesions - in this case, in the MIN-Os.

From the whole genome analysis of MIN-O and tumor samples by the array CGH, we found that most lesions already have chromosome aberrations at the MIN-O stage. The results from the expression arrays mirror the CGH results in that major expression changes were seen in the MIN-O stage and expression changes between the MIN-Os and tumors are surprisingly relatively few. The finding that the MIN-Os already have the major genomic and expression changes that have previously been associated with tumorigenesis is consistent with observations in human breast cancer $[3,4]$. Human DCIS has been found to have the same chromosome alterations found in inva- 
Table I2: Significant biological functions for MIN-O vs PL expression differences for $8 \mathrm{w}-\mathrm{D}$ line

\begin{tabular}{|c|c|c|}
\hline Name & GO ID & Corrected P-value \\
\hline \multicolumn{3}{|l|}{ Response to radiation/UV } \\
\hline phototransduction & GO:0007602 & $0.00 \mathrm{E}+00$ \\
\hline detection of light & GO:0009583 & $0.00 \mathrm{E}+00$ \\
\hline response to radiation & GO:0009314 & $0.00 \mathrm{E}+00$ \\
\hline response to light & GO:00094I6 & $0.00 \mathrm{E}+00$ \\
\hline response to UV & GO:00094II & $2.88 \mathrm{E}-02$ \\
\hline \multicolumn{3}{|l|}{ Apoptosis } \\
\hline apoptotic program & GO:0008632 & $0.00 \mathrm{E}+00$ \\
\hline \multicolumn{3}{|l|}{ Immune response } \\
\hline complement activation, classical pathway & GO:0006958 & $9.56 \mathrm{E}-03$ \\
\hline positive regulation of immune response & GO:0050778 & I.15E-02 \\
\hline regulation of immune response & GO:0050776 & I.36E-02 \\
\hline T-cell activation & GO:0042II0 & $2.23 \mathrm{E}-02$ \\
\hline antigen processing & GO:0030333 & $2.25 \mathrm{E}-02$ \\
\hline cellular defense response (sensu Vertebrata) & GO:0016066 & $2.32 \mathrm{E}-02$ \\
\hline antimicrobial humoral response & GO:0019730 & $2.58 \mathrm{E}-02$ \\
\hline positive regulation of lymphocyte activation & GO:005I25I & $2.60 \mathrm{E}-02$ \\
\hline xenobiotic metabolism & GO:0006805 & $2.58 \mathrm{E}-02$ \\
\hline symbiotic interaction between host and other organism & GO:0044404 & $2.56 \mathrm{E}-02$ \\
\hline oxygen and reactive oxygen species metabolism & GO:0006800 & $3.21 \mathrm{E}-02$ \\
\hline complement activation & GO:0006956 & $3.21 \mathrm{E}-02$ \\
\hline response to xenobiotic stimulus & GO:0009410 & $3.97 \mathrm{E}-02$ \\
\hline lymphocyte differentiation & GO:0030098 & $3.94 \mathrm{E}-02$ \\
\hline pathogenesis & GO:0009405 & $3.96 \mathrm{E}-02$ \\
\hline T-helper I type immune response & GO:0042088 & 4.19E-02 \\
\hline detection of biotic stimulus & GO:0009595 & 4.49E-02 \\
\hline cytokine and chemokine mediated signaling pathway & GO:0019221 & $4.72 \mathrm{E}-02$ \\
\hline antigen presentation, endogenous antigen & GO:0019883 & 4.7IE-02 \\
\hline lymphocyte proliferation & GO:004665I & 4.90E-02 \\
\hline antigen presentation & GO:0019882 & 8.19E-03 \\
\hline \multicolumn{3}{|l|}{ Angiogenesis } \\
\hline blood vessel morphogenesis & GO:00485I4 & $8.92 \mathrm{E}-03$ \\
\hline blood vessel development & GO:000I568 & I.I7E-02 \\
\hline angiogenesis & GO:000I525 & $1.47 \mathrm{E}-02$ \\
\hline \multicolumn{3}{|l|}{ ECM } \\
\hline extracellular structure organization and biogenesis & GO:0043062 & $3.18 \mathrm{E}-02$ \\
\hline extracellular matrix organization and biogenesis & GO:0030198 & 3.15E-02 \\
\hline cell-matrix adhesion & GO:0007I60 & $4.3 \mathrm{IE}-02$ \\
\hline \multicolumn{3}{|l|}{ Signaling pathways } \\
\hline I-kappaB kinase/NF-kappaB cascade & GO:0007249 & $0.00 \mathrm{E}+00$ \\
\hline regulation of I-kappaB kinase/NF-kappaB cascade & GO:0043I 22 & $2.38 \mathrm{E}-02$ \\
\hline positive regulation of I-kappaB kinase/NF-kappaB cascade & GO:0043I 23 & $2.35 \mathrm{E}-02$ \\
\hline Wnt receptor signaling pathway & GO:0016055 & $1.16 \mathrm{E}-04$ \\
\hline Ras protein signal transduction & GO:0007265 & 4.6IE-03 \\
\hline inactivation of MAPK & GO:0000188 & $2.43 \mathrm{E}-02$ \\
\hline \multicolumn{3}{|l|}{ Steroid } \\
\hline steroid biosynthesis & GO:0006694 & $3.27 \mathrm{E}-06$ \\
\hline sterol metabolism & GO:0016125 & 4.16E-02 \\
\hline
\end{tabular}

sive ductal carcinoma [3]. In addition, at the gene expression level, ADH, DCIS, and IDC from the same individual are highly similar to each other [4,37].

Our findings show whole chromosome gains in the MINOs and tumors to be fairly common, while no whole chromosome loss was observed. This is consistent with LOH analysis that did not find increased chromosome loss or large deletions in $\mathrm{Tg}(\mathrm{PyVmT})$ mammary tumor [38]. A previous CGH study by Hodgson et al. found that chromosomes 2, 11 and 15 most often had recurrent gains in PyVmT mammary tumors [24]. Indeed, the tumor samples we analyzed frequently had whole chromosome gains of these chromosomes, as well as chromosomes 1 
and 10. However, there were no genetic changes found consistently during the transition from MIN-O to tumor in the different lines. Moreover, as expected from the CGH analysis, there seem to be no common expression changes that are associated with every MIN-O to tumor transition event.

The whole genome analysis with aCGH also led to the identification of areas of small deletions. Moreover, using a custom-designed array, the aberrations were confirmed and the breakpoints were refined. The smallest area confirmed by the zoom-in array was the 59,704 bp deletion on chromosome 3, which spans only one known gene, 2810410M20Rik. The zoom-in array clearly demonstrated the loss of 56 probes that represented this stretch of chromosome 3 in MIN-Os and the corresponding tumor samples. Moreover, for the other two areas of deletion, the losses of DNA were confirmed to span the same areas in the MIN-Os and the tumors. In general, the same small aberrations as well as large gains were seen in both MIN-Os and tumors, suggesting that these genomic changes were already present in the MIN-Os.

Chromosome aberrations in human breast cancer has been studied with LOH analysis [39] and array CGH $[2,3,5,40-43]$. These studies have identified regions of frequent copy number changes in breast cancer. For example, ErbB2 amplicon on 17 q21 is amplified in $20-30 \%$ of breast cancers [44]. Frequent copy number changes of certain chromosome regions are associated with BRCA1 and BRCA2 tumors, and they can be classified by the genomic copy number alterations [40]. More recently, Fridlyand et al. has shown that breast tumors can be classified into three subtypes based on the copy number alteration phenotypes [45]. The "mixed amplifier" group had low level gains and losses with some recurring copy number changes, while the others two types had either few copy number changes ("1q/16q" group) or significant changes encompassing nearly $60 \%$ of the genome with copy number alterations ("complex" group). The patterns of genome alteration in our MIN-O lines resemble those of the first two groups. Interestingly, the majority of human tumors in these two groups were ER positive and that these two groups had better outcome compared to the complex group [45]. Our MIN-O lines may better represent human breast cancers that are low grade and less aggressive than those that are ER negative, high grade lesions with poor outcome.

\section{Major expression changes associated with tumorigenesis} Although there were no common genomic alterations found among all MIN-O samples examined, there seem to be common gene expression changes associated with the transition from normal mammary gland to MIN-O. For example, MIN-Os over-expressed cyclin D1 and Cdkn1a
(P21). Cyclin D1 is a well-known oncogene, which is commonly over-expressed in human breast cancer [46]. Moreover, recent reports demonstrated that cyclin D1associated kinase activity, through its association with CDK4, is required for ErbB2-dependent mammary tumorigenesis [47-49]. Cdkn1a (P21) was also significantly over-expressed in the MIN-Os. Cdkn1a is a cyclin-dependent kinase inhibitor and is commonly known to induce G1 arrest via the p53 pathway [50]. However this is not incongruous with Cdkn1a over-expression in the MIN-Os, as p21 is often over-expressed in human cancer, and more studies have shown p21 as a modulator of cell proliferation, rather than inhibitor [51,52]. Dysregulation of these genes in the MIN-Os demonstrates that although these tissues are phenotypically premalignant, the MIN-Os already have molecular changes known to be associated with tumorigenesis.

Since major molecular changes had occurred in the MINOs, tumors developed from the MIN-Os had surprisingly small genetic differences from the corresponding MIN-O tissues. Many genes coding for extracellular proteins were down-regulated in tumors. Among these genes, Lum and Gsn are two genes whose association with breast cancer has been well studied. Decreased expression of Lum is associated with poor outcome of invasive breast cancer [53] and down-regulation of Gsn is associated with breast cancer progression [54].

\section{Changes associated with aneuploidy}

Each MIN-O line, established from a distinct MIN lesion in the original transgenic mammary fat pad, has distinct genomic and expression profiles and biological characteristics. This is also similar to human DCIS lesions, because DCIS is subclassified into different histological grades and the pattern of chromosome alterations and gene expression signatures differs between different histological grades $[3,4]$. MIN-Os can be classified into subgroups by genomic and molecular profiles that reflect biological behavior (metastatic potential, tumor latency, estrogen sensitivity).

Genetically unstable MIN-O lines, which have multiple whole chromosome gains, almost always had gain of chromosome 2. AurkA was one of the genes on chromosome 2 that was highly over-expressed in these MIN-Os. AurkA is localized to the spindles and its overexpression induces aberrant mitosis that results in centrosome duplication and aneuploidy [55]. Overexpression of AurkA is associated with cancer, including human DCIS $[56,57]$. Other genes involved in mitotic spindle assembly and centrosome duplication were also over-expressed in these MIN-Os. Ran, Kif22/Kid, Plk1 and Nde1 [58] are important for mitotic spindle assembly [58-61]. Mitotic spindle components, tublins alpha1 and beta6 were both over- 
expressed. Plk1 also regulates centrosome assembly and separation, and controls the onset of G2/M transition in the cell cycle by activating cdc25c [62]. Interestingly, betatubulin and cdc25c are substrates of Plk1 [61]. Other substrates of Plk1 are subunits of anaphase promoting complex (APC), which regulates progression and exit through mitosis by proteolysis of cell cycle regulators [59]. Two APC related genes, a component of APC, Apc11, and an activator of APC, cdc20, were both up-regulated in these MIN-Os. APC/cdc20 complex is important for metaphase to anaphase transition [59]. These genes highlight dysregulation of G2/M phase, especially during metaphase/anaphase when sister chromatids and spindle poles separate.

\section{Changes associated with metastasis}

Highly metastatic MIN-O lines had alteration of genes involved in immune response and apoptotic processes. Recently, studies have shown that the inflammation process is closely linked to cancer development $[63,64]$. Innate immune systems promote tumorigenesis by producing factors that activate tumor associated cells and changes stromal microenvironment [65]. It is believed that changes in apoptotic tumor cell death pattern affect the tumor microenvironment and the associated immune response [66]. In particular, for the metastatic processes, tumor cells utilize many of the same factors, such as adhesion molecules, chemokines and receptors, used by inflammatory cells [67]. In the Tg(PyVmT) model, lack of functional macrophages inhibits the development of invasive mammary carcinoma and pulmonary metastasis [68], and other factors that regulate tumor microenvironment also affect the metastatic potential [69-72]. Gas6 is the ligand for Axl receptor tyrosine kinase, which regulates immune system and inhibits apoptosis $[73,74]$. Bcl6 is a transcriptional regulator that has an anti-apoptotic role and also affects humoral immune response [75]. Both of these genes were highly over-expressed in both metastatic MIN-O lines. Moreover, the expression of ICAM-1, an endothelial intercellular adhesion molecule was downregulated in these MIN-Os. ICAM-1 is known to be downregulated by tumor derived angiogenic factors in order to inhibit leukocyte infiltration and to escape from antitumor immune surveillance [76,77]. These expression changes suggest the alteration of the genes related to the immune modulation in these MIN-Os, which may contribute to the development of tumor associated environment that promote migration and invasion.

The "Metastatic signature gene set" [35] was not differentially expressed between the metastatic and non-metastatic MIN-O lines. This seems to be contradictory to the results by Qiu et al [36] in which the signature gene set was predictive of metastatic behaviour of $\mathrm{Tg}(\mathrm{PyVmT})$ tumors. However, this study compares MIN-Os with different metastatic potentials, which express PyVmT as the initiating oncogene in the same genetic background (FVB), and is fundamentally different from the study by Qiu et al in which $\mathrm{Tg}(\mathrm{PyVmT})$ tumors from various genetic backgrounds were compared. Thus, while the metastatic signature gene set may be effective in classifying metastatic disease from a group of genetically polymorphic samples, the MIN-O mouse lines will be useful for investigating specific molecular mechanisms responsible for metastasis in the disease tissues.

\section{Changes associated with estrogen dependence}

ER status of the MIN-Os, in general, reflected the ovarian hormone sensitivity of the lesions. The $8 \mathrm{w}-\mathrm{B}$ and $8 \mathrm{w}-\mathrm{D}$ lines, which were associated with nuclear ER-positive MIN-O cells, were the most sensitive to the ovariectomy. In all four MIN-O lines studied, significantly less ER-positive cells were found in the tumors from the intact hosts, and in the MIN-Os from the ovariectomized hosts.

Two common functions that were affected in the estrogen sensitive MIN-O lines were steroid biosynthesis and angiogenesis. Significance of these two functions as well as the expression differences in the ERs and aromatase may represent the difference in estrogen mediated signaling in the $8 \mathrm{w}-\mathrm{B}$ and D MIN-Os from the rest of the MIN-O lines, since estrogen modulates endothelial cell behavior, including angiogensis [78]. This concept is further supported by the dysregulation of genes that are known to be regulated by estrogen or ER, such as Cyp1b1 [79], Nf-kB2 [80], RelB, Strn [81], Fbln1 [82] or genes that interact with estrogen or ER, such as Abcg1, Gnai2, and Jun [83]. The down-regulation of two Nf-kB family members, Nf-kB2 and RelB, maybe significant since ER alpha is known to inhibit the Nf-kB activity by various mechanisms, including direct binding to the Nf-kB complex to inhibit transcriptional activation [80]. Jun was up-regulated in estrogen sensitive MIN-Os. ER activates transcription at AP-1 sites via interaction with Jun/Fos/coactivator complex [83]. Dysregulation of these genes seems to draw a picture of increase ER and estrogen activities in these MINOs.

\section{Conclusion}

In summary, in this mouse model of breast cancer, the majority of the molecular changes responsible for tumorigenesis are already present in early premalignant lesions. The progression to invasive carcinoma is associated with only few additional changes, and these changes are not common in all tumors. Moreover, the molecular heterogeneity of the premalignant lesions represents phenotypic differences of these lesions. Thus, the MIN-O mouse model recapitulates both the preencoding and heterogeneity found in early human breast lesions and may be used as a high fidelity model for the biology of human breast cancer. 


\section{List of abbreviations used}

comparative genomic hybridization (CGH), ductal carcinoma in situ (DCIS), estrogen receptor (ER), invasive ductal carcinoma (IDC), mammary intraepithelial neoplasia outgrowth (MIN-O), MIN (mammary intraepithelial neoplasia), polyomavirus middle-T (PyVmT), array comparative genomic hybridization (aCGH), Gene Ontology (GO)

\section{Competing interests}

The author(s) declare that they have no competing interests.

\section{Authors' contributions}

RN participated in the ovariectomy study, performed RNA isolation and gene expression analysis, and drafted the manuscript. JM established the MIN-O lines, and designed and performed the ovariectomy experiment. RD performed the gene expression microarrays and the array $\mathrm{CGH}$, and identified the chromosome aberrations. $\mathrm{CB}$ performed the GSR analysis and assisted with the gene expression analysis. SL was involved in transplant surgeries, MIN-O tissue collection and gene expression studies, as well as critical editing of this manuscript. CC performed the analysis of CGH data and designed the custom zoomin arrays. LY established the MIN-O lines and performed MIN-O transplant surgeries. $\mathrm{AB}$ and $\mathrm{RC}$ assisted in the histology analysis. $\mathrm{RC}$ also directed the establishment of the MIN-O lines and made this study possible. JG directed this study and helped draft the manuscript. All authors read and approved the final manuscript.

\section{Additional material}

\section{Additional File 1}

Cell cycle and cell death genes that are differentially expressed in MIN-Os. Lists of cell cycle and cell death genes that were differentially expressed $(p<0.01)$ in the MIN-Os when compared to the prelactating normal mammary gland controls.

Click here for file

[http://www.biomedcentral.com/content/supplementary/1471-

2407-6-275-S1.xls]

\section{Additional File 2}

Lists of tumors vs MIN-Os expression difference from each MIN-O line. Expression profiles from tumors and MIN-Os from each MIN-O line were compared and significant differences were identified $(p<0.01)$. Click here for file

[http://www.biomedcentral.com/content/supplementary/14712407-6-275-S2.xls]

\section{Additional File 3}

Differentially expressed genes on chromosome 2 that are common to MIN-O lines with whole chromosome losses. Among the differentially expressed gene lists $(p<0.01)$ of $8 w-B$ and $4 w-4 M I N-O$ lines, genes on chromosome 2 that are common to both lists were identified. Click here for file

[http://www.biomedcentral.com/content/supplementary/14712407-6-275-S3.xls]

\section{Additional File 4}

Differentially expressed genes $(p<0.01)$ that are specific to the two $M I N-O$ lines with high metastatic index. From the lists of differentially expressed genes from each MIN-O lines, genes that are only specific to $4 w$ 11 and $8 w$-D were identified.

Click here for file

[http://www.biomedcentral.com/content/supplementary/14712407-6-275-S4.xls]

\section{Additional File 5}

Expression differences of ER and aromatase between ovarian hormone sensitive and less sensitive MIN-Os. ERalpha, ERbeta, and aromatase expression differences were compared between estrogen sensitive ( $8 w$ $B \& 8 w-D)$ and less sensitive ( $4 w-4 \& 4 w-11)$ MIN-O lines.

Click here for file

[http://www.biomedcentral.com/content/supplementary/14712407-6-275-S5.xls]

\section{Additional File 6}

Differentially expressed genes $(p<0.01)$ that are specific to estrogen sensitive MIN-Os. From the lists of differentially expressed genes from each MIN-O lines, genes that are only specific to $8 w-B$ and $8 w$-D were identified.

Click here for file

[http://www.biomedcentral.com/content/supplementary/14712407-6-275-S6.xls]

\section{Acknowledgements}

This work was supported by Grants IIIB-0I 23 (JPG) and 9FB-02I2 (RN) from the California Breast Cancer Research Program and the Investigator Initiated Grant by Department of Pathology at UC Davis. Processing and analysis of gene expression was done in Gene Expression Shared Resource (2 P30 CA93373-04, P30-ES05707). Processing and immunohistochemistry of fixed tissue was done in the mutant mouse pathology lab (CCM, UC Davis).

\section{References}

I. Fearon ER, Vogelstein B: A genetic model for colorectal tumorigenesis. Cell 1990, 6 I(5):759-767.

2. Chin K, de Solorzano CO, Knowles D, Jones A, Chou W, Rodriguez EG, Kuo WL, Ljung BM, Chew K, Myambo K, Miranda M, Krig S, Garbe J, Stampfer M, Yaswen P, Gray JW, Lockett SJ: In situ analyses of genome instability in breast cancer. Nat Genet 2004, 36(9):984-988.

3. Hwang ES, DeVries S, Chew KL, Moore DH 2nd, Kerlikowske K, Thor A, Ljung BM, Waldman FM: Patterns of chromosomal alterations in breast ductal carcinoma in situ. Clin Cancer Res 2004, I0(15):5160-5167.

4. Ma XJ, Salunga R, Tuggle JT, Gaudet J, Enright E, McQuary P, Payette T, Pistone M, Stecker K, Zhang BM, Zhou YX, Varnholt H, Smith B, Gadd M, Chatfield E, Kessler J, Baer TM, Erlander MG, Sgroi DC: Gene expression profiles of human breast cancer progression. Proc Natl Acad Sci U S A 2003, I 00( I 0):5974-5979. 
5. Aubele M, Mattis A, Zitzelsberger H, Walch A, Kremer M, Welzl G, Hofler $\mathrm{H}$, Werner M: Extensive ductal carcinoma In situ with small foci of invasive ductal carcinoma: evidence of genetic resemblance by CGH. Int J Cancer 2000, 85( I):82-86.

6. Perou CM, Sorlie T, Eisen MB, van de Rijn M, Jeffrey SS, Rees CA, Pollack JR, Ross DT, Johnsen H, Akslen LA, Fluge O, Pergamenschikov $A$ Williams C, Zhu SX, Lonning PE, Borresen-Dale AL, Brown PO, Botstein D: Molecular portraits of human breast tumours. Nature 2000, 406(6797):747-752.

7. Sorlie T, Perou CM, Tibshirani R, Aas T, Geisler S, Johnsen H, Hastie T, Eisen MB, van de Rijn M, Jeffrey SS, Thorsen T, Quist H, Matese JC, Brown PO, Botstein D, Eystein Lonning P, Borresen-Dale AL: Gene expression patterns of breast carcinomas distinguish tumor subclasses with clinical implications. Proc Natl Acad Sci U S A 200I, 98(I9): I0869-I0874.

8. van 't Veer LJ, Dai $H$, van de Vijver MJ, He YD, Hart AA, Mao M, Peterse HL, van der Kooy K, Marton MJ, Witteveen AT, Schreiber G], Kerkhoven RM, Roberts C, Linsley PS, Bernards R, Friend SH: Gene expression profiling predicts clinical outcome of breast cancer. Nature 2002, 4I5(687I):530-536.

9. Mallon E, Osin P, Nasiri N, Blain I, Howard B, Gusterson B: The basic pathology of human breast cancer. J Mammary Gland Biol Neoplasia 2000, 5(2): I39-163.

10. Shoker BS, Sloane JP: DCIS grading schemes and clinical implications. Histopathology 1999, 35(5):393-400.

II. Maglione JE, McGoldrick ET, Young LJ, Namba R, Gregg JP, Liu L, Moghanaki D, Ellies LG, Borowsky AD, Cardiff RD, MacLeod CL: Polyomavirus middle T-induced mammary intraepithelial neoplasia outgrowths: single origin, divergent evolution, and multiple outcomes. Mol Cancer Ther 2004, 3(8):94I-953.

12. Namba R, Maglione JE, Young LJ, Borowsky AD, Cardiff RD, MacLeod $\mathrm{CL}$, Gregg JP: Molecular characterization of the transition to malignancy in a genetically engineered mouse-based model of ductal carcinoma in situ. Mol Cancer Res 2004, 2(8):453-463.

13. Cardiff RD, Anver MR, Gusterson BA, Hennighausen L, Jensen RA, Merino MJ, Rehm S, Russo J, Tavassoli FA, Wakefield LM, Ward JM, Green JE: The mammary pathology of genetically engineered mice: the consensus report and recommendations from the Annapolis meeting. Oncogene 2000, $19(8): 968-988$.

14. Maglione JE, Moghanaki D, Young LJ, Manner CK, Ellies LG, Joseph SO, Nicholson B, Cardiff RD, MacLeod CL: Transgenic Polyoma middle-T mice model premalignant mammary disease. Cancer Res 200I, 6 I (22):8298-8305.

15. Namba R, Young LJ, Maglione JE, McGoldrick ET, Liu S, Wurz GT, DeGregorio MW, Borowsky AD, MacLeod CL, Cardiff RD, Gregg JP: Selective estrogen receptor modulators inhibit growth and progression of premalignant lesions in a mouse model of DCIS. Breast Cancer Res 2005, 7(6):R88I-889.

16. RepeatMasker [http://www.repeatmasker.org]

17. Hughes TR, Mao M, Jones AR, Burchard J, Marton MJ, Shannon KW, Lefkowitz SM, Ziman M, Schelter JM, Meyer MR, Kobayashi S, Davis C, Dai H, He YD, Stephaniants SB, Cavet G, Walker WL, West A, Coffey E, Shoemaker DD, Stoughton R, Blanchard AP, Friend SH, Linsley PS: Expression profiling using microarrays fabricated by an ink-jet oligonucleotide synthesizer. Nat Biotechnol 200I, 1 9(4):342-347.

18. Agilent Technologies [http://www.chem.agilent.com]

19. Barrett MT, Scheffer A, Ben-Dor A, Sampas N, Lipson D, Kincaid R, Tsang P, Curry B, Baird K, Meltzer PS, Yakhini Z, Bruhn L, Laderman $S$ : Comparative genomic hybridization using oligonucleotide microarrays and total genomic DNA. Proc Natl Acad Sci U S A 2004, I 01 (5 I): I7765-17770.

20. Ermine] software [http://microarray.cu-genome.org/erminel/]

21. Lee HK, Braynen W, Keshav K, Pavlidis P: ErmineJ: tool for functional analysis of gene expressiono data sets. $B M C$ Bioinformatics 2005, 6:269.

22. UCSC Genome Browser [http://genome.ucsc.edu/cgi-bin/ hgGateway]

23. Lin EY, Jones JG, Li P, Zhu L, Whitney KD, Muller WJ, Pollard JW: Progression to malignancy in the polyoma middle $\mathbf{T}$ oncoprotein mouse breast cancer model provides a reliable model for human diseases. Am J Pathol 2003, I 63(5):2। I3-2I 26.

24. Hodgson JG, Malek T, Bornstein S, Hariono S, Ginzinger DG, Muller WJ, Gray JW: Copy number aberrations in mouse breast tumors reveal loci and genes important in tumorigenic receptor tyrosine kinase signaling. Cancer Res 2005, 65(2I):9695-9704.

25. Anderson DM, Maraskovsky E, Billingsley WL, Dougall WC, Tometsko ME, Roux ER, Teepe MC, DuBose RF, Cosman D, Galibert L: A homologue of the TNF receptor and its ligand enhance $T$ cell growth and dendritic-cell function. Nature 1997, 390(6656): I75-I79.

26. Lim KH, Baines AT, Fiordalisi J], Shipitsin M, Feig LA, Cox AD, Der C], Counter CM: Activation of RalA is critical for Ras-induced tumorigenesis of human cells. Cancer Cell 2005, 7(6):533-545.

27. Gery S, Tanosaki S, Bose S, Bose N, Vadgama J, Koeffler HP: Downregulation and growth inhibitory role of C/EBPalpha in breast cancer. Clin Cancer Res 2005, I I (9):3 I84-3190.

28. Grimm SL, Rosen JM: The role of C/EBPbeta in mammary gland development and breast cancer. J Mammary Gland Biol Neoplasia 2003, 8(2): 19|-204.

29. Shi B, Vinyals A, Alia P, Broceno C, Chen F, Adrover M, Gelpi C, Price JE, Fabra A: Differential expression of MHC class II molecules in highly metastatic breast cancer cells is mediated by the regulation of the CIITA transcription Implication of CIITA in tumor and metastasis development. Int J Biochem Cell Biol 2006, 38(4):544-562.

30. TamiolakisI D, Venizelos I, Lambropoulou M, Jivannakis T, Seliniotakis E, Tsikouras P, Limberis V, Tsalkidis A, Papadopoulos N: Gains and losses of HLA class II (DR) and CD4 in atypical hyperplasia, carcinoma in situ and infiltrating ductal carcinoma of the breast. Acta Medica (Hradec Kralove) 2004, 47(4):257-262.

31. Eckerdt F, Yuan J, Strebhardt K: Polo-like kinases and oncogenesis. Oncogene 2005, 24(2):267-276.

32. Kinch MS, Carles-Kinch K: Overexpression and functional alterations of the EphA2 tyrosine kinase in cancer. Clin Exp Metastasis 2003, 20(I):59-68.

33. Ren B, Cam H, Takahashi Y, Volkert T, Terragni J, Young RA, Dynlacht BD: E2F integrates cell cycle progression with DNA repair, replication, and G(2)/M checkpoints. Genes Dev 2002, 16(2):245-256.

34. Holland SJ, Powell MJ, Franci C, Chan EW, Friera AM, Atchison RE, McLaughlin J, Swift SE, Pali ES, Yam G, Wong S, Lasaga J, Shen MR, Yu S, Xu W, Hitoshi Y, Bogenberger J, Nor JE, Payan DG, Lorens JB: Multiple roles for the receptor tyrosine kinase axl in tumor formation. Cancer Res 2005, 65(20):9294-9303.

35. Ramaswamy S, Ross KN, Lander ES, Golub TR: A molecular signature of metastasis in primary solid tumors. Nat Genet 2003, 33(I):49-54.

36. Oiu TH, Chandramouli GV, Hunter KW, Alkharouf NW, Green JE, Liu ET: Global expression profiling identifies signatures of tumor virulence in MMTV-PyMT-transgenic mice: correlation to human disease. Cancer Res 2004, 64(I 7):5973-598I.

37. Schuetz CS, Bonin M, Clare SE, Nieselt K, Sotlar K, Walter M, Fehm T, Solomayer E, Riess O, Wallwiener D, Kurek R, Neubauer HI: Progression-specific genes identified by expression profiling of matched ductal carcinomas in situ and invasive breast tumors, combining laser capture microdissection and oligonucleotide microarray analysis. Cancer Res 2006, 66(10):5278-5286.

38. Ritland SR, Rowse G], Chang Y, Gendler SJ: Loss of heterozygosity analysis in primary mammary tumors and lung metastases of MMTV-MTAg and MMTV-neu transgenic mice. Cancer Res I997, 57( I 6):3520-3525.

39. Wang ZC, Lin M, Wei LJ, Li C, Miron A, Lodeiro G, Harris L, Ramaswamy S, Tanenbaum DM, Meyerson M, Iglehart JD, Richardson A: Loss of heterozygosity and its correlation with expression profiles in subclasses of invasive breast cancers. Cancer Res 2004, 64(I):64-7I.

40. Jonsson G, Naylor TL, Vallon-Christersson J, Staaf J, Huang J, Ward MR, Greshock JD, Luts L, Olsson H, Rahman N, Stratton M, Ringner $M$, Borg A, Weber BL: Distinct genomic profiles in hereditary breast tumors identified by array-based comparative genomic hybridization. Cancer Res 2005, 65(I7):76/2-762I.

4I. Gunther K, Merkelbach-Bruse S, Amo-Takyi BK, Handt S, Schroder $W$, Tietze $L$ : Differences in genetic alterations between primary lobular and ductal breast cancers detected by comparative genomic hybridization. J Pathol 200I, 193(I):40-47.

42. Yao J, Weremowicz S, Feng B, Gentleman RC, Marks JR, Gelman R, Brennan C, Polyak K: Combined cDNA array comparative genomic hybridization and serial analysis of gene expression 
analysis of breast tumor progression. Cancer Res 2006, 66(8):4065-4078

43. O'Connell P: Genetic and cytogenetic analyses of breast cancer yield different perspectives of a complex disease. Breast Cancer Res Treat 2003, 78(3):347-357.

44. Slamon DJ, Godolphin W, Jones LA, Holt JA, Wong SG, Keith DE, Levin WJ, Stuart SG, Udove J, Ullrich A, et al:: Studies of the HER $2 /$ neu proto-oncogene in human breast and ovarian cancer. Science 1989, 244(4905):707-7| 2.

45. Fridlyand J, Snijders AM, Ylstra B, Li H, Olshen A, Segraves R, Dairkee S, Tokuyasu T, Ljung BM, Jain AN, McLennan J, Ziegler J, Chin K, Devries S, Feiler H, Gray JW, Waldman F, Pinkel D, Albertson DG: Breast tumor copy number aberration phenotypes and genomic instability. BMC Cancer 2006, 6:96.

46. Sutherland RL, Musgrove EA: Cyclin DI and mammary carcinoma: new insights from transgenic mouse models. Breast Cancer Res 2002, 4(I): I4-17.

47. Landis MW, Pawlyk BS, Li T, Sicinski P, Hinds PW: Cyclin DIdependent kinase activity in murine development and mammary tumorigenesis. Cancer Cell 2006, 9(I):| 3-22.

48. Reddy HK, Mettus RV, Rane SG, Grana X, Litvin J, Reddy EP: Cyclindependent kinase 4 expression is essential for neu-induced breast tumorigenesis. Cancer Res 2005, 65(22): $10174-10178$.

49. Yu Q, Sicinska E, Geng Y, Ahnstrom M, Zagozdzon A, Kong Y, Gardner $\mathrm{H}$, Kiyokawa $\mathrm{H}$, Harris LN, Stal O, Sicinski P: Requirement for CDK4 kinase function in breast cancer. Cancer Cell 2006 , 9(I):23-32.

50. Liu G, Lozano G: p2 I stability: linking chaperones to a cell cycle checkpoint. Cancer Cell 2005, 7(2): | |3-| | 4.

5I. Weiss RH: p2IWafI/CipI as a therapeutic target in breast and other cancers. Cancer Cell 2003, 4(6):425-429.

52. Yuste L, Montero JC, Esparis-Ogando A, Pandiella A: Activation of ErbB2 by overexpression or by transmembrane neuregulin results in differential signaling and sensitivity to herceptin. Cancer Res 2005, 65(1 5):680I-6810.

53. Troup S, Njue C, Kliewer EV, Parisien M, Roskelley C, Chakravarti S, Roughley PJ, Murphy LC, Watson PH: Reduced expression of the small leucine-rich proteoglycans, lumican, and decorin is associated with poor outcome in node-negative invasive breast cancer. Clin Cancer Res 2003, 9(1):207-2I4.

54. Winston JS, Asch HL, Zhang PJ, Edge SB, Hyland A, Asch BB: Downregulation of gelsolin correlates with the progression to breast carcinoma. Breast Cancer Res Treat 200 I, 65(I):II-2I.

55. Meraldi P, Honda R, Nigg EA: Aurora-A overexpression reveals tetraploidization as a major route to centrosome amplification in p53-/- cells. Embo J 2002, 21 (4):483-492.

56. Hoque A, Carter J, Xia W, Hung MC, Sahin AA, Sen S, Lippman SM: Loss of aurora A/STKI5/BTAK overexpression correlates with transition of in situ to invasive ductal carcinoma of the breast. Cancer Epidemiol Biomarkers Prev 2003, I 2( I 2): I 5 | 8-1522.

57. Miyoshi Y, Iwao K, Egawa C, Noguchi S: Association of centrosomal kinase STK I 5/BTAK mRNA expression with chromosomal instability in human breast cancers. Int / Cancer 200I, 92(3):370-373.

58. Feng $\mathrm{Y}, \mathrm{Walsh} \mathrm{CA}$ : Mitotic spindle regulation by Ndel controls cerebral cortical size. Neuron 2004, 44(2):279-293.

59. Castro A, Bernis C, Vigneron S, Labbe JC, Lorca T: The anaphasepromoting complex: a key factor in the regulation of cell cycle. Oncogene 2005, 24(3):3|4-325.

60. Peters JM: The anaphase-promoting complex: proteolysis in mitosis and beyond. Mol Cell 2002, 9(5):93 I-943

61. van Vugt MA, Medema RH: Getting in and out of mitosis with Polo-like kinase-I. Oncogene 2005, 24(I7):2844-2859.

62. Myer DL, Bahassi el M, Stambrook PJ: The Plk3-Cdc25 circuit. Oncogene 2005, 24(2):299-305.

63. Coussens LM, Werb Z: Inflammation and cancer. Nature 2002 420(69|7):860-867.

64. Philip M, Rowley DA, Schreiber H: Inflammation as a tumor promoter in cancer induction. Semin Cancer Biol 2004 | 4(6):433-439.

65. Bissell MJ, Radisky D: Putting tumours in context. Nat Rev Cancer 200I, I(I):46-54.

66. Zeh HJ 3rd, Lotze MT: Addicted to death: invasive cancer and the immune response to unscheduled cell death. J Immunother 2005, 28(I): I-9.
67. Muller A, Homey B, Soto H, Ge N, Catron D, Buchanan ME, McClanahan T, Murphy E, Yuan W, Wagner SN, Barrera JL, Mohar A, Verastegui E, Zlotnik A: Involvement of chemokine receptors in breast cancer metastasis. Nature 200I, 4l 0(6824):50-56.

68. Lin EY, Pollard JW: Macrophages: modulators of breast cancer progression. Novartis Found Symp 2004, 256:158-68; discussion 168-72, 259-69.

69. Forrester E, Chytil A, Bierie B, Aakre M, Gorska AE, Sharif-Afshar AR, Muller WJ, Moses HL: Effect of conditional knockout of the type II TGF-beta receptor gene in mammary epithelia on mammary gland development and polyomavirus middle $T$ antigen induced tumor formation and metastasis. Cancer Res 2005, 65(6):2296-2302.

70. Muraoka-Cook RS, Kurokawa H, Koh Y, Forbes JT, Roebuck LR, Barcellos-Hoff MH, Moody SE, Chodosh LA, Arteaga CL: Conditional overexpression of active transforming growth factor betal in vivo accelerates metastases of transgenic mammary tumors. Cancer Res 2004, 64(24):9002-90II.

7I. Muraoka RS, Dumont N, Ritter CA, Dugger TC, Brantley DM, Chen J, Easterly E, Roebuck LR, Ryan S, Gotwals PJ, Koteliansky V, Arteaga CL: Blockade of TGF-beta inhibits mammary tumor cell viability, migration, and metastases. J Clin Invest 2002, I09(12):155।-1559.

72. Bugge TH, Lund LR, Kombrinck KK, Nielsen BS, Holmback K, Drew AF, Flick MJ, Witte DP, Dano K, Degen JL: Reduced metastasis of Polyoma virus middle $T$ antigen-induced mammary cancer in plasminogen-deficient mice. Oncogene 1998, 16(24):3097-3104.

73. Lee WP, Wen Y, Varnum B, Hung MC: Akt is required for AxIGas6 signaling to protect cells from EIA-mediated apoptosis. Oncogene 2002, 21 (3):329-336.

74. Schwartzberg PL: Immunology. Tampering with the immune system. Science 200I, 293(5528):228-229.

75. Phan RT, Dalla-Favera R: The BCL6 proto-oncogene suppresses p53 expression in germinal-centre B cells. Nature 2004, 432(70 i 7):635-639.

76. Bouma-ter Steege JC, Baeten Cl, Thijssen VL, Satijn SA, Verhoeven IC, Hillen HF, Wagstaff J, Griffioen AW: Angiogenic profile of breast carcinoma determines leukocyte infiltration. Clin Cancer Res 2004, I 0(2 I):7I7I-7I78.

77. Griffioen AW, Damen CA, Martinotti S, Blijham GH, Groenewegen G: Endothelial intercellular adhesion molecule-I expression is suppressed in human malignancies: the role of angiogenic factors. Cancer Res 1996, 56(5): IIIII-IIII.

78. Cid MC, Schnaper HW, Kleinman HK: Estrogens and the vascular endothelium. Ann N Y Acad Sci 2002, 966: 143-157.

79. Tsuchiya Y, Nakajima M, Yokoi T: Cytochrome P450-mediated metabolism of estrogens and its regulation in human. Cancer Lett 2005, 227(2): II5-124.

80. Kalaitzidis D, Gilmore TD: Transcription factor cross-talk: the estrogen receptor and NF-kappaB. Trends Endocrinol Metab 2005, I 6(2):46-52.

8I. Lu Q, Pallas DC, Surks HK, Baur WE, Mendelsohn ME, Karas RH: Striatin assembles a membrane signaling complex necessary for rapid, nongenomic activation of endothelial NO synthase by estrogen receptor alpha. Proc Natl Acad Sci U S A 2004, I0I(49): I7|26-17|3|.

82. Moll F, Katsaros D, Lazennec G, Hellio N, Roger P, Giacalone PL, Chalbos D, Maudelonde T, Rochefort H, Pujol P: Estrogen induction and overexpression of fibulin-IC mRNA in ovarian cancer cells. Oncogene 2002, 2 I(7): I097-II 07.

83. Kushner PJ, Agard DA, Greene GL, Scanlan TS, Shiau AK, Uht RM, Webb P: Estrogen receptor pathways to AP-I. J Steroid Biochem Mol Biol 2000, 74(5):3II-3I7.

\section{Pre-publication history}

The pre-publication history for this paper can be accessed here:

http://www.biomedcentral.com/1471-2407/6/275/pre pub 